Check for updates

Cite this: Mater. Chem. Front., 2020, 4, 1328

Received 15th October 2019

Accepted 25th February 2020

DOI: $10.1039 / c 9 q m 00639 g$

rsc.li/frontiers-materials

\title{
The power of dissociation: development of displacement assays for chemosensing and latent catalytic systems $\dagger$
}

\author{
Cheuk-Fai Chow, (D)* Anxun Zheng, Min Huang and Chang Shen
}

\begin{abstract}
Disassembly is an essential process in supramolecular chemistry, and its exploitation has resulted in the development of four different displacement assays: (a) indicator-displacement assay (IDA), (b) indicator/ catalyst-displacement assay (ICDA), (c) catalytic/indicator-displacement assay (CIDA), and (d) catalystdisplacement assay (CDA). These consist of bimetallic donor-acceptor ensembles (BmDAEs), which incorporate various metallic signal transducers, receptors, inhibitors, catalysts, and pre-catalysts. Applications thereof include pollutant degradation, signal amplification, chemosensing detection, and latent catalysis. This review discusses the use of bimetallic supramolecular systems for the development of catalysts, chemosensors, and chemodosimeters.
\end{abstract}

\section{Introduction}

Supramolecular chemistry is the study of the association, dissociation, and exchange of molecules. ${ }^{1}$ Reversibility and dynamics are the characteristics that originate from these three processes. ${ }^{2}$ Initially, during the development of supramolecular chemistry, much attention was focused on exploiting intermolecular interactions to self-assemble molecules to create functional materials, ${ }^{3 a}$ catalysts, ${ }^{3 b}$ chemosensors, ${ }^{3 c}$ drug delivery vehicles, ${ }^{3 d}$ and molecular machines. ${ }^{3 e}$ Recently, the molecular exchange has been used to show the adaptability and evolution of supramolecular systems in response to environmental changes. ${ }^{4}$ However, the disassembly in supramolecular chemistry remains relatively underexplored..$^{5-7}$

Disassembly and its reverse process (self-assembly) are ubiquitous and significant in nature. A well-established example of these processes is cytoskeleton dynamics, in which the constant dissociation and association of actin filaments mediate cell growth, motility, and membrane internalization. ${ }^{5}$ Based on the same principle, various sensing disassembly assays, including antibody-based immunoassays, ${ }^{6 a}$ enzyme-linked immunosorbent assays, ${ }^{6 b}$ and indicator displacement assays, ${ }^{6 c}$ have been developed to detect antigens, proteins, and pollutants, respectively, for clinical diagnoses, biopharmaceutical analysis, environmental monitoring, and food testing. These detections often use the presence of an analyte to dissociate the intermolecular interaction(s) of

Department of Science and Environmental Studies, The Education University of Hong Kong, 10 Lo Ping Road, Tai Po Hong Kong SAR, China.

E-mail: cfchow@eduhk.hk

$\dagger$ Dedicated to Professor Jean Marie Lehn on the occasion of his 80th birthday. receptor-chromophore ensemble by forming a new receptoranalyte adduct and releasing a chromophore for chemosensing detection. Another significant application of supramolecular disassembly assays is in the development of latent catalytic systems, in which a "smart off-on" catalytic function is achieved by the use of heat, light, mechanical stimuli, or chemical agents to cleave an inhibitor from the catalyst. ${ }^{7}$

Bimetallic donor-acceptor ensembles (BmDAEs) are of particular interest in the chemosensing and catalytic sciences. The judicious choice of the employed transition metals, ligands, and bridging units allows the tuning of the intrinsic structural, catalytic, spectroscopic, and spectrofluorometric properties of the bimetallic-based systems, ${ }^{8}$ and the bifunctional properties of the latter can be rationally controlled for synergistic ${ }^{9 a}$ or antagonistic ${ }^{9 b}$ sensing and catalytic effects. While recent reports have covered several different perspectives of supramolecular chemistry, this review will focus mainly on the recent developments of disassembly assay-based bimetallic donor-acceptor catalytic and chemosensing systems based on the disassembly assays as vital tools for pollutant degradation and detection.

\section{Indicator-displacement assay (IDA) for chemodosimetric detection}

The incidence of hazardous toxic substances and persistent organic pollutants in food and in the environment can create significant problems for society. The development of practical molecular detectors for toxic chemicals represents a novel solution to this problem. Over the past decades, significant studies on the use of supramolecular chemosensors and chemodosimeters 
for the detection of toxins in food, environmental pollutants, and metabolites in living organisms have been reported. ${ }^{10}$ Synthetic design, binding and signal triggering mechanisms, sensing reversibility, selectivity, and sensitivity are the essential factors that must be considered for the development of these detecting systems. By definition, both chemosensors and chemodosimeters are molecular detectors composed of a recognition unit (binding site) and a signal transduction unit (signaling site) linked by a covalent ${ }^{11 a}$ and/or supramolecular interaction. ${ }^{11 b, c}$ In the presence of an analyte, the signal transducer produces a sensing response, such as electrochemical, ${ }^{12 a}$ color, ${ }^{12 b}$ and/or luminescent change ${ }^{12 c}$ via its interaction(s) with the receptor. ${ }^{12}$ Although both types of supramolecular devices have been developed for molecular detection, chemosensors are suitable for reversible and real-time detection, whereas chemodosimeters are used for irreversible and cumulative detection. ${ }^{13}$

Supramolecular dissociation has become a useful tool for the development of chemodosimeters. Recently, indicator displacement assays (IDAs) have been exploited as an irreversible approach to detect analytes. ${ }^{14 a-e}$ This assay uses the dissociation of the supramolecular linkage(s) between the recognition and signal transduction units induced by the analyte to produce a dosimetric signal. The working principle of the IDA involves (i) initial binding of a chromophore to a receptor forming a "receptor-indicator ensemble", (ii) introduction of a competitive analyte into the system, causing dissociation of the ensemble and triggering of an optical signal from the release of an indicator, and (iii) formation of a new "receptor-analyte adduct". The irreversibility of these processes enhances the suitability of chemodosimeters particularly for quality monitoring, as the detection of pollution, spoilage or disease is unequivocal.

\subsection{Bimetallic donor-acceptor ensembles (BmDAEs)}

We have developed a series of BmDAEs for the IDA detection of zwitterions, ${ }^{15 a, b}$ anions, ${ }^{15 c, d}$ and neutral organic molecules. ${ }^{15 e-j}$ The following section covers the effect of variation of the (i) metallic receptor (MA), (ii) metallic signal-transducer (MB), (iii) auxiliary ligands (Ligand), and (iv) bridging unit (Bridge), on the chemodosimetric selectivity and sensitivity of the BmDAE (Scheme 1).

The BmDAE $\mathrm{Ru}^{\mathrm{II}}(\text { phen })_{2}(\mathrm{CN})_{2}-\left[\mathrm{Pt}^{\mathrm{II}}(\mathrm{DMSO}) \mathrm{Cl}_{2}\right]_{2}$ (1, phen = 1,10-phenanthroline and DMSO = dimethyl sulfoxide) was prepared for the detection of amino acids in aqueous media (Fig. 1). ${ }^{15 a}$ The three metal centers in the BmDAE adopt a V-shaped configuration. The two $\mathrm{Pt}^{\mathrm{II}}(\mathrm{DMSO}) \mathrm{Cl}_{2}$ receptors recognize the

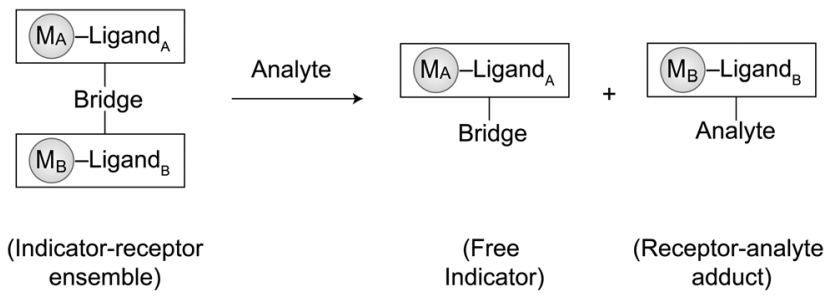

Scheme 1 Bimetallic donor-acceptor ensemble (BmDAEs) for the detection of analytes via the IDA.

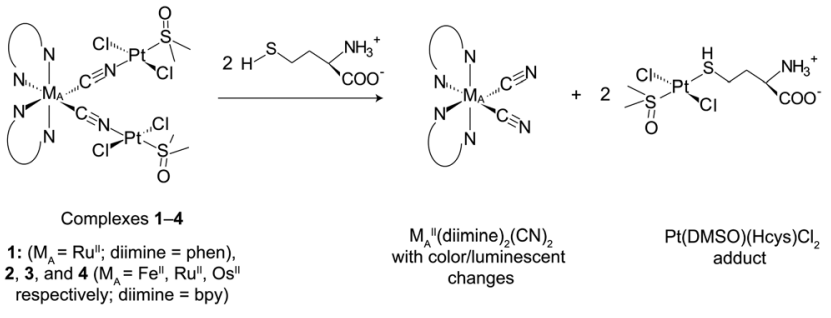

Fig. 1 The detection of Hcys by complexes 1-4 via the IDA.

sulfide moieties (R-SH) ${ }^{16 a}$ of amino acids and quench the triplet metal-to-ligand charge transfer ( ${ }^{3} \mathrm{MLCT}$ ) luminescence of the $\mathrm{Ru}^{\mathrm{II}}$ diimine center. ${ }^{16 b}$ The formation of $\mathbf{1}$ is shown in eqn (1), and its Gibbs free energy $\left(\Delta G^{\circ}\right)$ was determined to be $-24.6 \mathrm{~kJ} \mathrm{~mol}^{-1}$ by the expression $\Delta G^{\circ}=-R T \ln K$, where $R$ is the universal gas constant, $T$ is the temperature, and $K$ is the experimental formation constant (determined at $1 \mathrm{~atm}$ and $298 \mathrm{~K}$ ), unless otherwise stated.

$$
\begin{aligned}
\mathrm{Ru}^{\mathrm{II}}(\text { phen })_{2}(\mathrm{CN})_{2}+2 \mathrm{Pt}^{\mathrm{II}}(\mathrm{DMSO})_{2} \mathrm{Cl}_{2} \\
\rightarrow \mathrm{Ru}^{\mathrm{II}}(\text { phen })_{2}(\mathrm{CN})_{2}-\left[\mathrm{Pt}^{\mathrm{II}}(\mathrm{DMSO}) \mathrm{Cl}_{2}\right]_{2}+2 \mathrm{DMSO}
\end{aligned}
$$

$$
\text { Hcys }+\mathrm{Pt}^{\mathrm{II}}(\mathrm{DMSO})_{2} \mathrm{Cl}_{2} \rightarrow \mathrm{Pt}^{\mathrm{II}}(\mathrm{DMSO})(\text { Hcys }) \mathrm{Cl}_{2}+\mathrm{DMSO}
$$

From eqn (1), it is expected that any amino acids that can form a more stable $\mathrm{Pt}^{\mathrm{II}}$ (DMSO)(amino acid) $\mathrm{Cl}_{2}$ adduct with the receptors in 1 will cause the BmDAE to dissociate, releasing $\mathrm{Ru}^{\mathrm{II}}$ (phen $)_{2}(\mathrm{CN})_{2}$. The sulfide group in homocysteine (Hcys: HOOC- $\left.\mathrm{CH}\left(\mathrm{NH}_{2}\right) \mathrm{CH}_{2} \mathrm{CH}_{2}-\mathrm{SH}\right)$ was used to test this hypothesis. The $\Delta G^{\circ}$ of eqn (2) was determined to be $-27.4 \mathrm{~kJ} \mathrm{~mol}^{-1}$. In the presence of Hcys, the dissociation of $\mathrm{Pt}^{\mathrm{II}}$ from the bridging $\mathrm{CN}$ ligands was concomitant with the formation of the more stable $\mathrm{Pt}^{\mathrm{II}}$ (DMSO)(Hcys)Cl $\mathrm{Cl}_{2}$ complex, which was detected by ESI-MS. This disassembly not only resulted in the formation of $\mathrm{Pt}^{\mathrm{II}}-\mathrm{Hcys}$ adduct, but also in the release of $\mathrm{Ru}^{\mathrm{II}}(\mathrm{phen})_{2}(\mathrm{CN})_{2}$ which triggered a luminescent change. Finally, the generated optical signal was directly proportional to the concentration of Hcys (Fig. 1).

\subsection{Tuning the IDA sensitivity by varying the $M_{A}$ unit in BmDAEs}

To achieve high sensitivity for an IDA, a chromotropic donor that can produce a large optical change upon cleavage of the bimetallic donor-acceptor linkage is key to success. A common strategy is to use the dissociation to disrupt the electron-transfer mechanism in the BmDAE, so that the metallic signal-transducer exhibits two different optical outputs in its free and bound phases during the IDA. The solvatochromic studies of $\mathrm{M}_{\mathrm{A}}^{\mathrm{II}}(\mathrm{bpy})_{2}(\mathrm{CN})_{2}\left(\mathrm{M}_{\mathrm{A}}^{\mathrm{II}}=\mathrm{Fe}^{\mathrm{II}}, \mathrm{Ru}^{\mathrm{II}}\right.$, and $\mathrm{Os}^{\mathrm{II}}$; and bpy $=2,2^{\prime}$-bipyridine) revealed that the MLCT transitions of these complexes can undergo a large Stokes shift by coordination of an electron metallic acceptor via its cyano-bridges. ${ }^{16 c}$ Therefore, the three bimetallic complexes $\mathrm{M}_{\mathrm{A}}^{\mathrm{II}}(\mathrm{bpy})_{2}(\mathrm{CN})_{2}-\left[\mathrm{Pt}^{\mathrm{II}}(\mathrm{DMSO}) \mathrm{Cl}_{2}\right]_{2}$ with $\mathrm{M}_{\mathrm{A}}^{\mathrm{II}}=\mathrm{Fe}^{\mathrm{II}}(2), \mathrm{Ru}^{\mathrm{II}}(3)$, and $\mathrm{Os}^{\mathrm{II}}$ (4) were synthesized for the detection of Hcys (Fig. 2). ${ }^{15 b}$ The crystal structures of complexes 2-4 reveal a V-shaped configuration with two $\mathrm{Pt}(\mathrm{DMSO}) \mathrm{Cl}_{2}$ acceptors bonded to their 


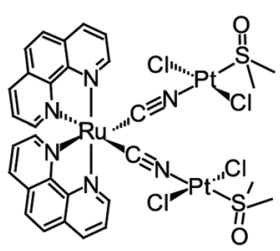

Complex 1
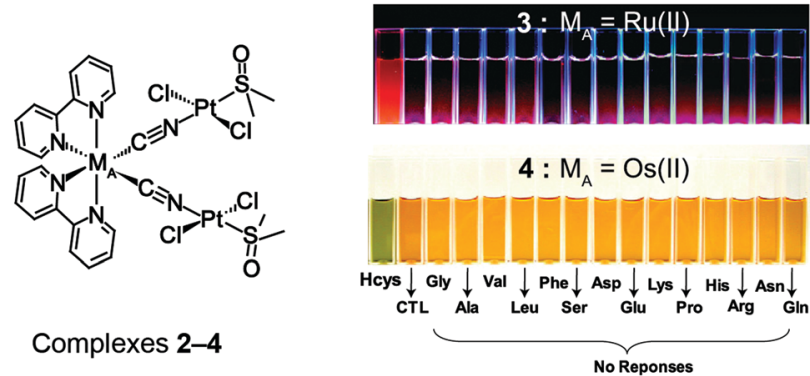

Complexes 2-4

Fig. 2 Structures and chemodosimetric responses of the BmDAEs, 2-4, towards different amino acids in an aqueous medium.

corresponding $\mathrm{M}_{\mathrm{A}}^{\mathrm{II}}$ donor through cyano bridges. The calculated $\Delta G^{\circ}$ of the formation of 2,3 , and 4 were $-24.5 \mathrm{~kJ} \mathrm{~mol}^{-1}$, $-24.6 \mathrm{~kJ} \mathrm{~mol}^{-1}$, and $-25.5 \mathrm{~kJ} \mathrm{~mol}^{-1}$, respectively. Under the abovementioned mechanism (Section 2.1), all complexes could detect Hcys via the IDA (the $\Delta G^{\circ}$ of $\mathrm{Pt}^{\mathrm{II}}(\mathrm{DMSO})(\mathrm{Hcys}) \mathrm{Cl}_{2}$ is $-27.4 \mathrm{~kJ} \mathrm{~mol}^{-1}$ ). Interestingly, by using different chromotropic signal transducers in the BmDAEs, different colorimetric or luminometric responses could be observed. In the presence of Hcys, the yellowish-orange complex 2 yielded a reddish-purple optical colorimetric signal, while the yellow complex 4 changed to greenish-yellow and the weakly luminescent complex 3 provided a strong orange luminescence. The optical responses originated from the perturbance of the MLCT and ${ }^{3}$ MLCT of signal transducers, $\mathrm{M}_{\mathrm{A}}^{\mathrm{II}}(\mathrm{bpy})_{2}(\mathrm{CN})_{2}$, upon assembly and disassembly with the $\mathrm{Pt}^{\mathrm{II}}$ acceptor. ${ }^{16 d}$ The detection limits of complexes 2, 3, and 4 for Hcys were $17.4 \mathrm{mg} \mathrm{L}^{-1}, 5.4 \mathrm{mg} \mathrm{L}^{-1}$, and $13.9 \mathrm{mg} \mathrm{L}^{-1}$, respectively. ${ }^{17}$

\subsection{Tuning the IDA selectivity by varying the BmDAEs components}

2.3.1 Varying the $\mathbf{M}_{B}$ receptor unit in BmDAEs. The development of BmDAEs for the selective IDA detection of analytes without perturbation by interferences is essential. A straightforward method involves the use of a specific receptor, $\mathrm{M}_{\mathrm{B}}$, to achieve excellent selectivity. ${ }^{18} \mathrm{~A} \mathrm{Ru}^{\mathrm{II}}-\mathrm{Cu}^{\mathrm{II}}$-based $\mathrm{BmDAE},\left\{\mathrm{Ru}^{\mathrm{II}}\left({ }^{t} \mathrm{Bub}\right.\right.$ py) $\left.(\mathrm{CN})_{4}-\left[\mathrm{Cu}^{\mathrm{II}}(\text { dien })\right]_{2}\right\}\left(\mathrm{ClO}_{4}\right)_{2}\left(\mathbf{5},{ }^{t}\right.$ Bubpy $=4,4^{\prime}$-di-tert-butyl-2,2' bipyridine and dien = diethylenetriamine) ${ }^{15 c}$ was synthesized for the detection of the extremely toxic cyanide anion (Fig. 3a). ${ }^{19}$ The $\mathrm{Cu}^{\mathrm{II}}$ metallic receptor was chosen not only because it coordinates the cyanide strongly in aqueous media, ${ }^{20}$ but also because if functions as a luminescent quencher for the ${ }^{3}$ MLCT of $\left[\mathrm{Ru}^{\mathrm{II}}\left({ }^{t} \mathrm{Bubpy}\right)(\mathrm{CN})_{4}\right]^{2-}$. The crystallographic analysis of 5 reveals a one-dimensional polymeric structure in which the $\mathrm{Ru}^{\mathrm{II}}$ metallic centers are cyano-bridged to two $\mathrm{Cu}^{\mathrm{II}}$ receptors each. In the spectroscopic and spectrofluorimetric titration experiments with $\mathbf{5}$, (a)
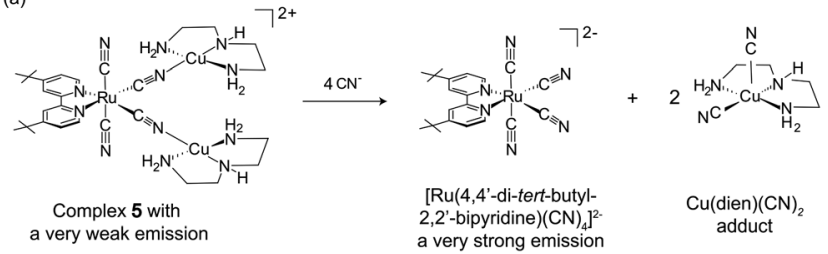

(b)

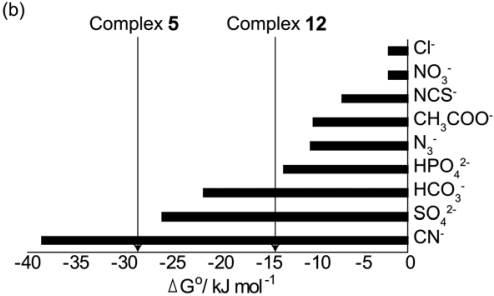

Fig. 3 (a) The detection of cyanide by complex 5 via the IDA; (b) binding strengths $\left(\Delta G^{\circ}\right)$ of various [Cu(dien)-analyte] adducts. The vertical lines represent the $\Delta G^{\circ}$ values of complexes 5 and 12

the selective chemodosimetric response to the cyanide anion consisted of a color change from green to orange and a luminescence change from nil to orange. No optical and luminescent signals were generated by $\mathbf{5}$ in the presence of potentially interfering anions (including $\mathrm{SO}_{4}{ }^{2-}, \mathrm{HCO}_{3}{ }^{-}, \mathrm{HPO}_{4}{ }^{2-}, \mathrm{N}_{3}{ }^{-}$, $\mathrm{CH}_{3} \mathrm{COO}^{-}, \mathrm{NCS}^{-}, \mathrm{NO}_{3}{ }^{-}$, and $\mathrm{Cl}^{-}$). The detection limit of 5 for cyanide was determined to be $0.03 \mathrm{mg} \mathrm{L}^{-1}$. A detailed thermodynamic study was performed to explain the observed selectivity. Fig. $3 \mathrm{~b}$ shows the $\Delta G^{\circ}$ of the formation of various [ $\mathrm{Cu}^{\mathrm{II}}$ (dien)anion] adducts. Only the $\left[\mathrm{Cu}^{\mathrm{II}}(\operatorname{dien})(\mathrm{CN})_{2}\right]$ adduct exhibited a smaller $\Delta G^{\circ}\left(-37.9 \mathrm{~kJ} \mathrm{~mol}^{-1}\right)$ than that of $5\left(-29.1 \mathrm{~kJ} \mathrm{~mol}^{-1}\right)$. This suggests that the driving force for the cleavage of 5 by $\mathrm{CN}^{-}$ is the formation of the more stable $\left[\mathrm{Cu}^{\mathrm{II}}(\operatorname{dien})(\mathrm{CN})_{2}\right]$ species, which explains the selectivity of 5 toward cyanide.

By changing the metallic receptor from $\mathrm{Cu}^{\mathrm{II}}$ to $\mathrm{Nd}^{\mathrm{III}}$, an acceptor which is well-known to have a strong affinity to amino group, a $\mathrm{Ru}^{\mathrm{II}}-\mathrm{Nd}^{\mathrm{III}}$-based BmDAE, $\mathrm{K}\left\{\left[\mathrm{Nd}^{\mathrm{III}}\left(\mathrm{H}_{2} \mathrm{O}\right)_{4}\right]-\left[\mathrm{Ru}^{\mathrm{II}}\left({ }^{t} \mathrm{Bubpy}\right)-\right.\right.$ $\left.\left.(\mathrm{CN})_{4}\right]_{2}\right\}$ (6) was synthesized for detecting biogenic amine. Histamine, which is one of the most important biogenic amines and the causative agent of scombroid poisoning, ${ }^{21,22}$ is of particular interest due to its impact in areas ranging from biomarkers of diseases $^{21 d}$ and to quality control of foodstuffs. ${ }^{21 e}$ Complex 6 was formed by stirring two equivalents of $\mathrm{K}_{2}\left[\mathrm{Ru}^{\mathrm{II}}\left({ }^{t} \mathrm{Bubpy}\right)(\mathrm{CN})_{4}\right]$ with one molar equivalent of $\mathrm{Nd}^{\mathrm{III}}\left(\mathrm{NO}_{3}\right)_{3}$. hydrate in a water/ methanol mixture in an open atmosphere at 298 K. Fig. 4 shows its molecular structure, in which two independent $\left[\mathrm{Ru}^{\mathrm{II}}\left({ }^{t} \mathrm{Bubpy}\right)(\mathrm{CN})_{4}\right]^{2-}$ units and one $\mathrm{Nd}^{\mathrm{III}}$ center are connected by two $\mathrm{Ru}^{\mathrm{II}}-\mathrm{C} \equiv \mathrm{N}-\mathrm{Nd}^{\mathrm{III}}$ cyanide bridges, forming a V-shaped configuration. ${ }^{15 f}$ Upon exposure of different biogenic vapors to complex $\mathbf{6}$, only histamine induced a spectrofluorometric enhancement of the testing solution, whereas other common food odor chemicals including aniline, $\mathrm{H}_{2} \mathrm{~S}, \mathrm{CO}, \mathrm{N}_{2}, \mathrm{CH}_{4}, \mathrm{H}_{2}$, and atmospheric air did not induce any observable spectrofluorometric changes. It was found that the detection proceeded via the abovementioned IDA mechanism, in which the cyano-bridges of the trinuclear complex $\left(\mathrm{CN}-\mathrm{Nd}^{\mathrm{III}}\right)$ are cleaved after binding of histamine to the 
(a)

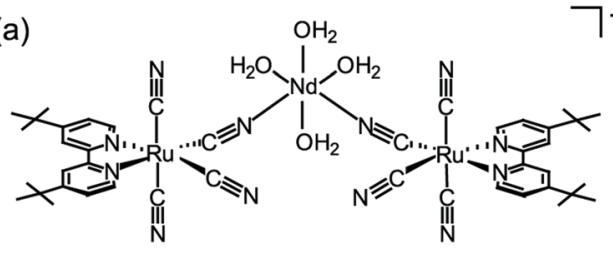

Complex 6

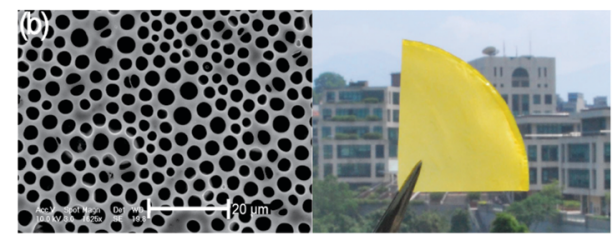

Fig. 4 (a) The structure of complex 6; (b) the photos of a porous polystyrene film where the sub-micron rods of complex 6 were immobilized.

lanthanide center. The observation of $\left.\left\{\mathrm{K}\left[\mathrm{Ru}^{\mathrm{II}}{ }^{t} \mathrm{Bubpy}\right)(\mathrm{CN})_{4}\right]\right\}^{-}$ $(\mathrm{m} / \mathrm{z}=513)$ in the electrospray ionization mass spectrometry of the complex 6-histamine mixture confirmed this suggestion. A solid-supported chemodosimetric material for histamine sensing was fabricated by blending submicron-rods of complex 6 (length $=2.1 \pm 0.6 \mu \mathrm{m}$ and width $=230 \pm 15 \mu \mathrm{m}$ ) with a porous polystyrene film (Fig. 4b). ${ }^{15 f}$ The detection limit of the prepared system for histamine vapor was $15 \mathrm{mg} \mathrm{L}^{-1}$.

2.3.2 Varying the bridging unit in BmDAEs. The development of an appropriate supramolecular linkage between the receptor and the indicator in BmDAEs is another key for achieving a high chemodosimetric selectivity of the IDA. If the bridge between the donor and acceptor is too strong, the analyte cannot dissociate the ensemble, whereas a too weak linkage is susceptible to dissociation by interferents. The two $\mathrm{Re}^{\mathrm{I}}$-bridge- $\mathrm{Pt}^{\mathrm{II}}$ BmDAEs $\left[\operatorname{Re}^{\mathrm{I}}{ }^{t}{ }^{t}{ }\right.$ ubpy $\left.)(\mathrm{CO})_{3}(\mathrm{NCS})\right]-\left[\mathrm{Pt}^{\mathrm{II}}(\mathrm{DMSO})(\mathrm{Cl})_{2}\right](7)$ and $\left[\mathrm{Re}^{\mathrm{I}}\left({ }^{t} \mathrm{Bubpy}\right)-\right.$ $\left.(\mathrm{CO})_{3}(\mathrm{CN})\right]-\left[\mathrm{Pt}^{\mathrm{II}}(\mathrm{DMSO})(\mathrm{Cl})_{2}\right]$ (8), featuring different bridging linkages (isothiocyano- and cyano-bridge) were synthesized for the detection of mercapto-containing pesticides in freshwater (Fig. 5a). ${ }^{15 g}$ Complexes 7 and 8 were synthesized by stirring equimolar amounts of $\mathrm{Pt}(\mathrm{DMSO})_{2} \mathrm{Cl}_{2}$ and $\operatorname{Re}^{\mathrm{I}}\left({ }^{t} \mathrm{Bubpy}\right)(\mathrm{CO})_{3}(\mathrm{NCS})$ or $\operatorname{Re}^{\mathrm{I}}\left({ }^{t} \mathrm{Bubpy}\right)(\mathrm{CO})_{3}(\mathrm{CN})$, respectively, in methanol-chloroform mixture at ambient conditions. The $\nu_{\mathrm{N}}=\mathrm{C}=\mathrm{s}$ peak of $\mathrm{Re}\left({ }^{\mathrm{I}} \mathrm{Bubpy}\right)-$ $(\mathrm{CO})_{3}(\mathrm{NCS})$ at $2161 \mathrm{~cm}^{-1}$ shifted to $2088 \mathrm{~cm}^{-1}$ for 7 while

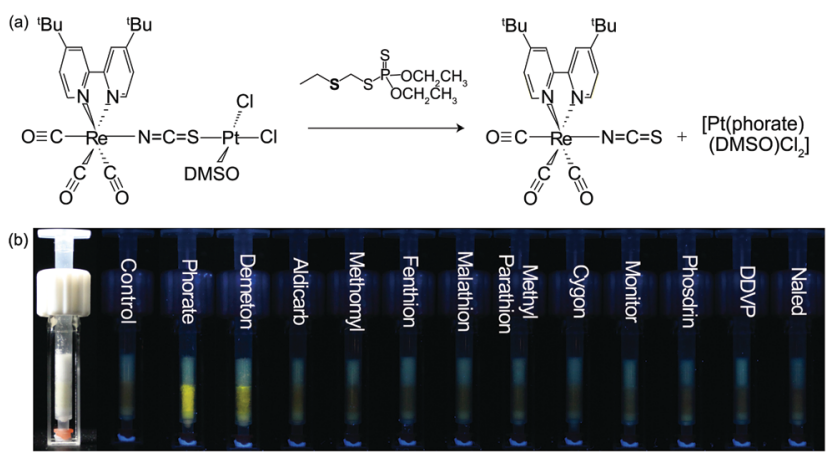

Fig. 5 (a) IDA of complex 7 for the detection of phorate; (b) photographs of the luminometric responses of the solid-supported chemodosimeter 7 with various pesticides (8.0 ppm). the $\nu_{\mathrm{C}=\mathrm{N}}$ peak of $\mathrm{Re}^{\mathrm{I}}\left({ }^{t} \mathrm{Bubpy}\right)(\mathrm{CO})_{3}(\mathrm{CN})$ at $2117 \mathrm{~cm}^{-1}$ shifted to $2182 \mathrm{~cm}^{-1}$ for 8 .

The spectrofluorimetric titrations revealed that, among the tested pesticides, only those containing an aliphatic mercapto functionality, such as phorate, induced a spectrofluorimetric response from 7. In contrast, pesticides with aromatic or conjugated mercapto functionalities, such as methomyl and fenthion, and with thiophosphates $(\mathrm{P}=\mathrm{S}$ and $\mathrm{P}-\mathrm{S})$, including malathion, methyl parathion, cygon, monitor, phosdrin, DDVP, and naled, did not produce any signal changes. Interestingly, all tested pesticides did not produce any spectrofluorimetric changes of the cyano-bridged complex 8. The $\Delta G^{\circ}$ values of complexes 7 and 8 were determined to be $-20.9 \mathrm{~kJ} \mathrm{~mol}^{-1}$ and $-22.4 \mathrm{~kJ} \mathrm{~mol}^{-1}$, respectively, whereas that of $\mathrm{Pt}^{\mathrm{II}}(\mathrm{DMSO})-$ (phorate) $\mathrm{Cl}_{2}$ is $-21.9 \mathrm{~kJ} \mathrm{~mol}^{-1}$. These results suggest that the control of the bridging linkage in $\mathrm{Re}^{\mathrm{I}}$-bridge-Pt $\mathrm{Pt}^{\mathrm{II}}$-based BmDAEs can lead to the regulation of their chemodosimetric selectivity. Furthermore, a solid-supported chemodosimetric device based on complex 7, fabricated by blending the complex with $\mathrm{Al}_{2} \mathrm{O}_{3}$, had a detection limit toward phorate of $0.48 \mathrm{mg} \mathrm{L}^{-1}$ (Fig. 5b).

2.3.3 Varying the ligand component on the $\mathrm{M}_{\mathrm{A}}$ signal transducer unit in BmDAEs. In addition to changing the receptor and the bridging unit of a BmDAE to achieve a specific chemodosimetric detection, varying the auxiliary ligand at the signal transducer results in selective detection. Three $\mathrm{Re}^{\mathrm{I}}-\mathrm{Pt}^{\mathrm{II}}$-based BmDAEs, ${ }^{15 h} \quad\left[\mathrm{Re}^{\mathrm{I}}(\right.$ diimine-ligand $\left.)(\mathrm{CO})_{3}(\mathrm{CN})\right]-\left[\mathrm{Pt}^{\mathrm{II}}(\mathrm{DMSO})(\mathrm{Cl})_{2}\right]$ [9 = 2,2'-biquinoline (biq), $10=5$-phenyl-1,10-phenanthroline (5-ph-phen), and $\mathbf{1 1}=$ bpy] were synthesized for the detection of dimethyl sulfide $\left(\mathrm{CH}_{3} \mathrm{SCH}_{3}\right)$, a biomarker used for testing the freshness of meats ${ }^{23}$ (Fig. 6). Complexes 9-11 are analogues of 8. The crystal structure of $\mathbf{9}$ reveals that the two metal centers in the complex adopt a linear configuration with one $\mathrm{Pt}(\mathrm{DMSO}) \mathrm{Cl}_{2}$ moiety bridged to the Re(I) center via cyano linkages.

The spectrofluorimetric titrations revealed that dimethyl sulfide induced a spectrofluorimetric response from 9 but not from 10 or 11. Other biogenic molecules, including dimethyl disulfide $\left(\mathrm{CH}_{3} \mathrm{SSCH}_{3}\right)$, dimethyl trisulfide $\left(\mathrm{CH}_{3} \mathrm{SSSCH}_{3}\right)$, 4-ethylphenol, triethylamine, propanoic acid, methane, and carbon monoxide, did not yield any spectrofluorimetric changes from 9, 10, and 11. Among these three BmDAEs, 9 has the largest formation energy owing to the extensive $\pi-\pi$ conjugation between the pyridine rings in biq (the $\Delta G^{\circ}$ of the formation

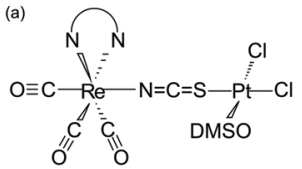

Complexes 9-11

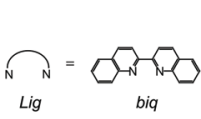

(9)

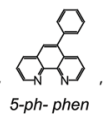

(10)

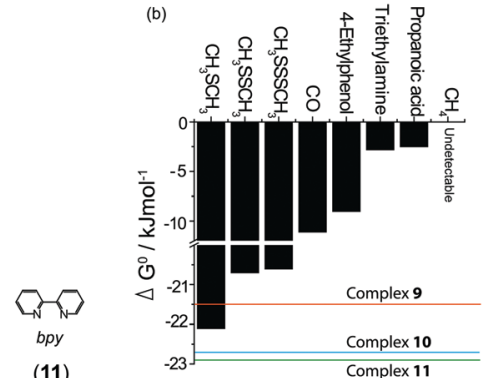

Fig. 6 (a) Structures of complexes 9-11; (b) binding strengths $\left(\Delta G^{\circ}\right)$ of the $\left[\mathrm{Pt}\right.$ "(DMSO) $\mathrm{Cl}_{2}$-analyte] adducts. The three horizontal lines represent the $\Delta G^{\circ}$ values of complexes 9-11. 
of 9, 10, and 11 are $-21.5 \mathrm{~kJ} \mathrm{~mol}^{-1},-22.7 \mathrm{~kJ} \mathrm{~mol}^{-1}$, and $-22.9 \mathrm{~kJ} \mathrm{~mol}^{-1}$, respectively), which also explains its specific chemodosimetric detection. Thus, the $\Delta G^{\circ}$ value of 9 was smaller than those of all the $\mathrm{Pt}^{\mathrm{II}}$-analyte adducts except for $\mathrm{Pt}^{\mathrm{II}}-\mathrm{CH}_{3} \mathrm{SCH}_{3}$ (the $\Delta G^{\circ}$ of its formation is $-22.1 \mathrm{~kJ} \mathrm{~mol}^{-1}$ ), and 9 selectively responded to $\mathrm{CH}_{3} \mathrm{SCH}_{3}$ (Fig. 6).

2.3.4 Varying the $\mathrm{M}_{\mathrm{A}}$ signal transducer unit in BmDAEs. A $\mathrm{Ru}^{\mathrm{II}}-\mathrm{Cu}^{\mathrm{II}}$-based BmDAE, $\left[\mathrm{Ru}^{\mathrm{II}}(\text { bpy })_{2}(\mathrm{CN})_{2}\right]-\left[\mathrm{Cu}^{\mathrm{II}}(\right.$ dien $\left.)\right]\left(\mathrm{ClO}_{4}\right)_{2}$ (12), was synthesized to study the effect of varying the signal transducer unit $\left(\mathrm{M}_{\mathrm{A}}\right)$ of BmDAE on the chemodosimetric selectivity. ${ }^{15 c}$ The main difference between complexes 12 and $\mathbf{5}$ is that the $\mathrm{Ru}^{\mathrm{II}}$-diimine donor in $\mathbf{5}$ possesses a net negative charge, while that of $\mathbf{1 2}$ is neutral. The donor-acceptor binding strength of $\mathbf{1 2}$ was expected to be weaker than that of $\mathbf{5}$. The $\Delta G^{\circ}$ of 12 was only $-14.8 \mathrm{~kJ} \mathrm{~mol}^{-1}$ which is larger than the $\left[\mathrm{Cu}^{\mathrm{II}}(\mathrm{dien})-\mathrm{CN}^{-} / \mathrm{SO}_{4}{ }^{2-} / \mathrm{HCO}_{3}{ }^{-}\right]$adducts $\left(-37.9 \mathrm{~kJ} \mathrm{~mol}^{-1}\right.$, $-26.6 \mathrm{~kJ} \mathrm{~mol}^{-1}$, and $-21.2 \mathrm{~kJ} \mathrm{~mol}^{-1}$, respectively, Fig. 3b). Hence, the spectrofluorometric titrations of $\mathbf{1 2}$ with the relevant anions showed non-selective results. $\mathrm{CN}^{-}, \mathrm{SO}_{4}{ }^{2-}$, and $\mathrm{HCO}_{3}{ }^{-}$ were able to cleave this analogue and produce the luminescent responses. The weaker metallic donor $\left(\mathrm{M}_{\mathrm{A}}\right)$ in $\mathbf{1 2}$ is the reason for its loss of selectivity.

\section{Indicator/catalyst-displacement assay (ICDA) for molecular detection and degradation}

Supramolecular devices that not only provide highly sensitive and selective detection but can also quickly degrade and mineralize persistent pollutants are highly sought after. In this section, a novel disassembly approach using BmDAEs, the so-called indicator/catalyst-displacement assay (ICDA), that features chemodosimetric detection, signal amplifying, and catalytic degradation of pollutants will be discussed. The concept of the ICDA resembles that of the IDA described above. However, another functional pair (i.e., inhibitor/catalyst) coexists with the signal transducer $\left(\mathrm{M}_{\mathrm{A}}\right)$ / receptor $\left(M_{B}\right)$ pair of a BmDAE. In this system, the metallic receptor, $M_{B}$, that also functions as a catalyst, first binds to the signal transducer, $\mathbf{M}_{\mathrm{A}}$, which is also an inhibitor. Then, a competitive analyte is introduced, causing the displacement of the signal transducer/inhibitor from the receptor/catalyst, which activates both the signal transducer and the catalyst. Ultimately, the analyte can be catalytically degraded into harmless components in a onestep process while its concentration is monitored (Scheme 2). For analytes that are not pollutants and do not require degradation, the released catalyst can be used for dye-formation/-degradation to achieve a higher sensitivity of detection (i.e., signal amplification).

\subsection{Selective chemodosimetric detection using the ICDA}

Two BmDAEs, $\left[\mathrm{Ru}^{\mathrm{II}}\left({ }^{t} \mathrm{Bubpy}\right)(\mathrm{CN})_{4}\right]_{2}-\left[\mathrm{Fe}^{\mathrm{III}}\left(\mathrm{H}_{2} \mathrm{O}\right)_{3} \mathrm{Cl}\right]_{2}(\mathbf{1 3})^{24}$ and $\left\{\mathrm{Fe}^{\mathrm{II}}\left({ }^{t} \mathrm{Bubpy}\right)(\mathrm{CN})_{4}-\left[\mathrm{Cu}^{\mathrm{II}}(\mathrm{dien})\right]_{2}\right\}\left(\mathrm{ClO}_{4}\right)_{2}(\mathbf{1 4}),{ }^{25}$ were synthesized for the detection of oxalic acid and cyanide, respectively, via an ICDA. Overuse of oxalic acid is common in rare-earth metal mining and causes freshwater pollution which can result in renal metabolic disorders. ${ }^{26}$

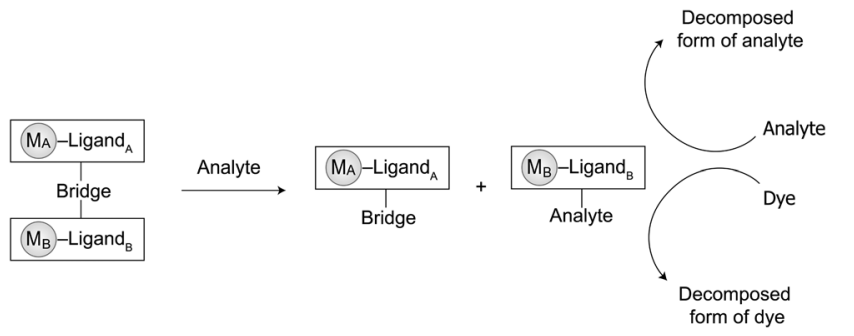

Scheme 2 BmDAEs for the detection, degradation, and signal amplification of analytes through the ICDA.

Complex 13 was formed by stirring equal equivalent molar of $\mathrm{FeCl}_{3}$ with $\mathrm{K}_{2}\left[\mathrm{Ru}\left({ }^{t} \mathrm{Bubpy}\right)(\mathrm{CN})_{4}\right]$ in deionized water. The tetranuclear structure was confirmed by ESI-MS and FTIR analysis, where the $\nu_{\mathrm{C}=\mathrm{N}}$ peaks of $\left[\mathrm{Ru}^{\mathrm{II}}\left({ }^{t} \mathrm{Bubpy}\right)(\mathrm{CN})_{4}\right]^{2-}$ at $2042 \mathrm{~cm}^{-1}$, $2058 \mathrm{~cm}^{-1}$, and $2093 \mathrm{~cm}^{-1}$ were shifted to $2030 \mathrm{~cm}^{-1}$, $2076 \mathrm{~cm}^{-1}$, and $2114 \mathrm{~cm}^{-1}$. Complex 13 was found to selectively detect oxalate in the presence of anions such as glyoxylate, pyruvate, tartrate, acetate, $\mathrm{SO}_{4}{ }^{2-}, \mathrm{HPO}_{4}{ }^{2-}, \mathrm{NO}_{3}{ }^{-}, \mathrm{N}_{3}{ }^{-}, \mathrm{CN}^{-}$, $\mathrm{NCS}^{-}$, and $\mathrm{Br}^{-}$. The selective spectroscopic and spectrofluorimetric signals were generated according to the abovementioned IDA mechanism and were attributed to the relative stability of $13\left(\Delta G^{\circ}=-18.0 \mathrm{~kJ} \mathrm{~mol}^{-1}\right)$ with respect to the $\mathrm{Fe}^{\mathrm{III}}$-oxalate adducts $\left(\Delta G^{\circ}=-20.1 \mathrm{~kJ} \mathrm{~mol}^{-1}\right)$. Using UV-vis spectroscopy, the visual detection limit of $\mathbf{1 3}$ for oxalate was determined to be $100 \mathrm{mg} \mathrm{L}^{-1}$.

Complex 14 is an analogue of complex 5 in which the $\mathrm{Ru}^{\mathrm{II}}$ luminophore is replaced by a $\mathrm{Fe}^{\mathrm{II}}$ chromophore. Each $\mathrm{Fe}^{\mathrm{II}}$ metallic center of $\mathbf{1 4}$ is cyano-bridged to two $\mathrm{Cu}^{\mathrm{II}}$ receptors. The IR spectroscopic analysis showed that the $\nu_{\mathrm{C}}=\mathrm{N}$ peaks of $\left[\mathrm{Fe}^{\mathrm{II}}\left({ }^{t} \mathrm{Bubpy}\right)(\mathrm{CN})_{4}\right]^{2-}$ at $2085 \mathrm{~cm}^{-1}, 2067 \mathrm{~cm}^{-1}$, and $2053 \mathrm{~cm}^{-1}$ were shifted to $2118 \mathrm{~cm}^{-1}, 2095 \mathrm{~cm}^{-1}, 2076 \mathrm{~cm}^{-1}$, and $2052 \mathrm{~cm}^{-1}$. The $\Delta G^{\circ}$ of 14 is $-27.0 \mathrm{~kJ} \mathrm{~mol}^{-1}$. Thus, the detection of cyanide by $\mathbf{1 4}$ proceeded via the same chemodosimetric mechanism as that by $\mathbf{5}$, and triggered a colorimetric signal (reddish-purple to light pink color change). The visual detection limit of $\mathbf{1 4}$ for cyanide ions was determined to be $32 \mathrm{mg} \mathrm{L}^{-1}$.

\subsection{Degradation through the ICDA}

The efficient degradation of persistent industrial pollutants is a major challenge. Therefore, the degradation properties of 13 and $\mathbf{1 4}$ for oxalate and cyanide, respectively, after their chemodosimetric detection have been investigated. The use of a $\mathrm{Fe}^{\mathrm{III}}$ species, which is released during the chemodosimetric detection of oxalate by 13 , as a photo-Fenton catalyst for the degradation of pollutants was studied. The photo-degradation studies showed that the released $\mathrm{Fe}^{\mathrm{III}}$-oxalate adduct is a good photo-Fenton's catalyst that can oxidize free oxalate left in the solution and achieve complete degradation of its organic content to $\mathrm{CO}_{2}$ within $6 \mathrm{~h}$ (Fig. 7). Oxalate degradation is achieved by hydroxyl radicals which are generated via the photo-Fenton mechanism from the released $\mathrm{Fe}^{\mathrm{III}}$-oxalate adducts according to eqn (3). ${ }^{27}$ This degradation is related to the disassembly of $\mathbf{1 3}$ by the introduction of oxalate, causing $\mathrm{Fe}^{\mathrm{III}}$ catalyst activation by breaking the cyano-linkages from the inhibitor, $\left[\mathrm{Ru}^{\mathrm{II}}\left({ }^{t} \mathrm{Bubpy}\right)(\mathrm{CN})_{4}\right]^{2-}$. 

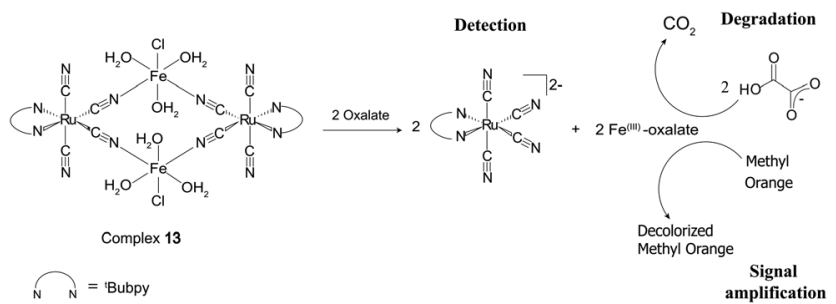

Fig. 7 The mechanism of oxalate detection by complex 13 via an ICDA, involving detection, degradation, and signal amplification.

Because common anions, such as glyoxylate, pyruvate, tartrate, acetate, $\mathrm{SO}_{4}{ }^{2-}, \mathrm{HPO}_{4}{ }^{2-}, \mathrm{NO}_{3}{ }^{-}, \mathrm{N}_{3}{ }^{-}, \mathrm{CN}^{-}, \mathrm{NCS}^{-}$, and $\mathrm{Br}^{-}$could not dissociate the BmDAE, complex 13 remained intact and the cyano-bridged $\mathrm{Fe}^{\mathrm{III}}$ catalyst remained inactive in the presence of potential interferents.

$$
\mathrm{Fe}^{3+}+\mathrm{H}_{2} \mathrm{O}+h \nu \rightarrow \mathrm{Fe}^{2+}+\mathrm{HO}^{\bullet}+\mathrm{H}^{+}
$$

To further demonstrate the scope of the ICDA, the catalytic oxidation of cyanide by $\left[\mathrm{Cu}^{\text {II }}(\right.$ dien $\left.)(\mathrm{CN})_{2}\right]$ adducts released from the chemodosimetric detection by complex 14 was investigated. Upon addition of cyanide to the ensemble, the displacement of $\left[\mathrm{Cu}^{\mathrm{II}}(\text { dien })\right]^{2+}$ from $\left[\mathrm{Fe}^{\mathrm{II}}\left({ }^{t} \mathrm{Bubpy}\right)(\mathrm{CN})_{4}\right]^{2-}$ afforded the $\left[\mathrm{Cu}^{\mathrm{II}}-\right.$ (dien) $\left.(\mathrm{CN})_{2}\right]$ adduct. Subsequently, the latter catalyzed the oxidation of free cyanide ions to the much less toxic cyanate using $\mathrm{H}_{2} \mathrm{O}_{2}$ as the oxidant within 240 min according to eqn (4) (Fig. 8). From the above results, we can note that the manipulation of the disassembly and assembly forms of the signal transducers of complexes $\mathbf{1 3}$ and $\mathbf{1 4}$ is the key for effective detection, while the disassembly and assembly of the BmDAE receptors enable tuning of the degradation properties.

$$
\mathrm{CN}^{-}+\mathrm{H}_{2} \mathrm{O}_{2} \rightarrow \mathrm{OCN}^{-}+\mathrm{H}_{2} \mathrm{O}
$$

\subsection{Signal amplification through the ICDA}

The detection of pollutants and analytes in low concentrations is essential for environmental monitoring. Although the increasing sophistication of analytical instruments leads to a decrease in the detection limits of many analytes, ultra-sensitive supramolecular detectors have been recently developed. Some chemical systems that can amplify weak input signals have been recently reported by Anslyn, ${ }^{9 a, 28}$ Prins, ${ }^{29}$ and others. ${ }^{30}$ However, smart molecular devices that can amplify reporting signals and simultaneously degrade pollutants via simple chemical design are rare.

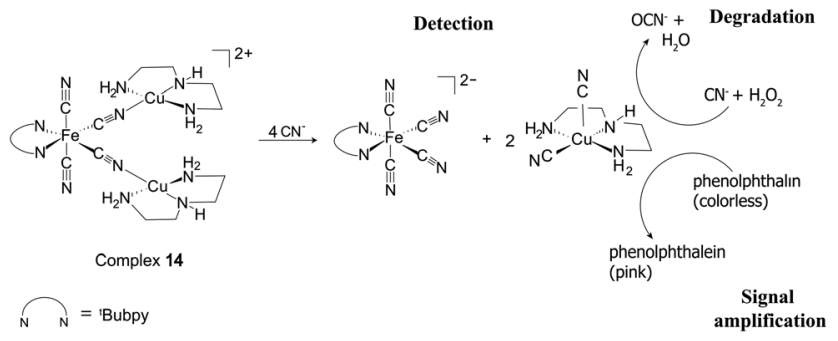

Fig. 8 The mechanism of cyanide detection by complex 14 via an ICDA, involving detection, degradation, and signal amplification.
Using methyl orange as an additional coloring agent, the signal amplification property of complex 13 in the detection of oxalate via the ICDA mechanism was demonstrated. Upon addition of oxalate to a solution of $\mathbf{1 3}$ and methyl orange, hydroxyl radicals generated from the aforementioned $\mathrm{Fe}^{\mathrm{III}}$-oxalate adduct-catalyzed photo-Fenton reaction not only mineralized the pollutant, but also led to decomposition of the added methyl orange, leading to a decrease in the intensity of the peak at $510 \mathrm{~nm}$. This caused a sharp color change with a visual detection limit as low as $2 \mathrm{mg} \mathrm{L}^{-1}$ (Fig. 7). Therefore, the sensitivity was amplified approximately 50-fold, from 100 to $2 \mathrm{mg} \mathrm{L}^{-1}$, through this catalytic amplification process.

Using phenolphthalein as the dye, complex 14 could also amplify the colorimetric cyanide detection signal 80-fold via the catalytic amplification (Fig. 8). It was found that, through the ICDA mechanism (Section 3.2), the released $\left[\mathrm{Cu}^{\mathrm{II}}(\operatorname{dien})(\mathrm{CN})_{2}\right]$ adduct acted as a catalyst for both the degradation of cyanide and the oxidation of phenolphthalein to phenolphthalein. Therefore, a pink color developed ( $a b s=551 \mathrm{~nm}$ ), resulting in a sharply magnified color change. The visual detection limit for the cyanide ion was as low as $0.4 \mathrm{mg} \mathrm{L}^{-1}$ due to the amplification, as opposed to $32 \mathrm{mg} \mathrm{L}^{-1}$ without the indicator.

\subsection{Changing the irreversible chemodosimetric detection to reversible chemosensing detection through ICDA}

Chemosensors differ from chemodosimeters in that they allow in-situ and reversible detection of analytes. ${ }^{13}$ A possible solution for the development of real-time and reversible sensing applications of BmDAEs consists in the use of ICDAs. Via the ICDA mechanism, not only the free analyte can be destroyed, but also the bound analyte from the receptor-analyte adduct can be degraded, thus releasing the free receptor into the matrix, and leading to the assembly of the original BmDAE.

A bimetallic complex, $(\mathrm{CN})_{3} \mathrm{Fe}^{\mathrm{II}}(\mathrm{tppz}) \mathrm{Cu}^{\mathrm{II}} \mathrm{Cl}(\mathbf{1 5}$, where tppz $=$ 2,3,5,6-tetra(2'-pyridyl)pyrazine), including a $\mathrm{Fe}^{\mathrm{II}}$-diimine MLCT indicator and a bifunctional $\mathrm{Cu}^{\mathrm{II}}$ catalyst/receptor was synthesized to demonstrate the reversible detection and detoxification of cyanide via the ICDA mechanism. ${ }^{31 a}$ Complex 15, which features a bridging tppz ligand, was synthesized by stirring equimo amounts of [benzyltriphenylphosphonium]-[Fe $\left.{ }^{\mathrm{II}}(\mathrm{tppz})(\mathrm{CN})_{3}\right]$ and $\mathrm{Cu}^{\mathrm{II}} \mathrm{Cl}_{2}$ in an aqueous ethanolic medium, and its structure is shown in Fig. 9a.

Complex 15 produced a selective colorimetric response from blue to purple in the presence of cyanide, without interference by other common anions $\left(\mathrm{CH}_{3} \mathrm{COO}^{-}, \mathrm{N}_{3}{ }^{-}, \mathrm{HCO}_{3}{ }^{-}, \mathrm{Cl}^{-}, \mathrm{NO}_{3}{ }^{-}\right.$, $\mathrm{HPO}_{4}{ }^{2-}, \mathrm{SO}_{4}{ }^{2-}, \mathrm{SCN}^{-}$, and $\left.\mathrm{OCN}^{-}\right)$. The colorimetric signal results from the dissociation of $15\left(\Delta G^{\circ}=-16.3 \mathrm{~kJ} \mathrm{~mol}^{-1}\right)$ into $\left[\mathrm{Fe}^{\mathrm{II}}(\mathrm{tppz})(\mathrm{CN})_{3}\right]^{-}$with concomitant formation of a more stable $\left[\mathrm{Cu}^{\mathrm{II}}(\mathrm{CN})_{4}\right]^{2-}$ adduct $\left(\Delta G^{\circ}=-125.5 \mathrm{~kJ} \mathrm{~mol}^{-1}\right) .{ }^{31 b}$ Fig. 9b (stage 1) shows the color changes in the test solution containing $\mathrm{CN}^{-}$, $\mathrm{H}_{2} \mathrm{O}_{2}$, and 15 (molar ratio of $10: 20: 1$ ) from 0 to $30 \mathrm{~min}$. Upon addition of cyanide, the color of the solution changes from blue (15) to purple $\left(\left[\mathrm{Fe}^{\mathrm{II}}(\mathrm{tppz})(\mathrm{CN})_{3}\right]^{-}\right.$and $\left.\left[\mathrm{Cu}^{\mathrm{II}}(\mathrm{CN})_{4}\right]^{2-}\right)$. Correspondingly, the portion of $\mathrm{CN}^{-}$decreased by $40 \%$ due to the formation of $\left[\mathrm{Cu}^{\mathrm{II}}(\mathrm{CN})_{4}\right]^{2-}$ (Fig. 9c, stage 1).

Fig. 9c (stage 2) shows that the formed $\left[\mathrm{Cu}^{\mathrm{II}}(\mathrm{CN})_{4}\right]^{2-}$ is the active catalyst of the oxidative degradation of free $\mathrm{CN}^{-}$to $\mathrm{OCN}^{-}$ in the presence of $\mathrm{H}_{2} \mathrm{O}_{2}$, and no UV-Vis spectroscopic changes 


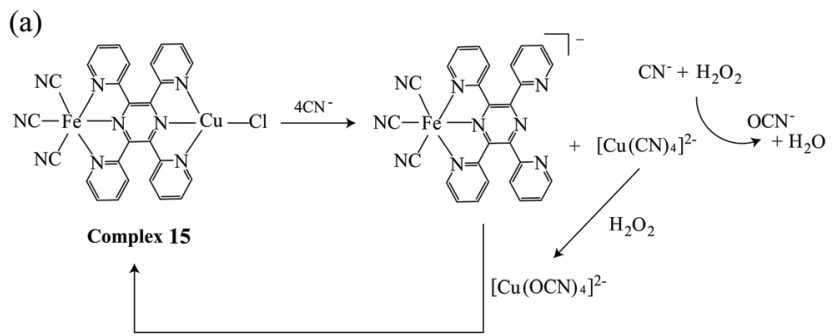

(b)

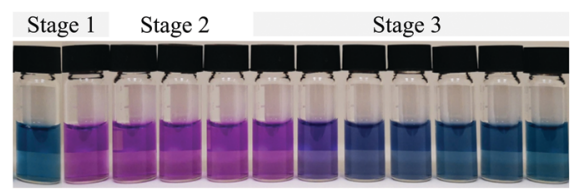

(c)

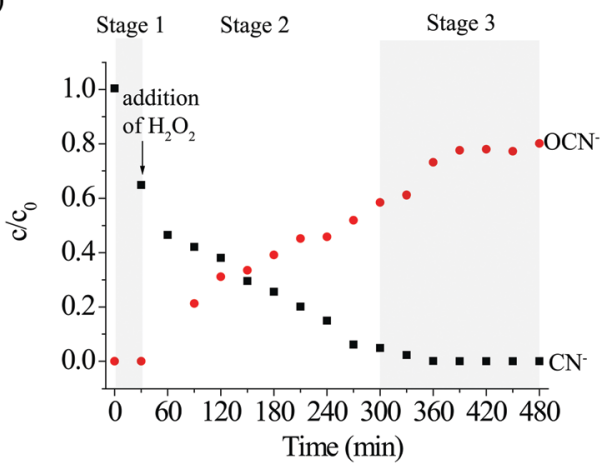

Fig. 9 Reversible detection of cyanide by 15 via the degradation of newly formed "receptor-cyanide ensemble", i.e. $\left[\mathrm{Cu}^{\prime \prime}(\mathrm{CN})_{4}\right]^{2-}$, under the ICDA.

for the test solution were observed (Fig. 9b, stage 2). Interestingly, the purple-colored $\left[\mathrm{Fe}^{\mathrm{II}}(\mathrm{tppz})(\mathrm{CN})_{3}\right]^{-}$solution gradually turned back to the original blue color during stage 3 (300-480 $\mathrm{min}$, Fig. 9b). We found that during the third stage, the bound cyanide ligands in $\left[\mathrm{Cu}^{\mathrm{II}}(\mathrm{CN})_{4}\right]^{2-}$ were further catalytically oxidized, in agreement with the increase in the portion of $\mathrm{OCN}^{-}$(Fig. 9c, stage 3). As the $\left[\mathrm{Cu}^{\mathrm{II}}(\mathrm{NCO})_{4}\right]^{2-}$ adduct $\left(\Delta G^{\circ}=-14.1 \mathrm{~kJ} \mathrm{~mol}^{-1}\right)$ is less stable than complex 15, regeneration of the BmDAE was favored.

\subsection{Fabrication of nano-materials for the detection and degradation of pollutants by the ICDA}

Recently, three Prussian blue bimetallic analogs (PBAs) namely $\mathrm{Fe}_{4}^{\mathrm{III}}\left[\mathrm{Fe}^{\mathrm{II}}(\mathrm{CN})_{6}\right]_{3^{-}}, \mathrm{Fe}_{4}^{\mathrm{III}}\left[\mathrm{Ru}^{\mathrm{II}}(\mathrm{CN})_{6}\right]_{3^{-}}$, and $\mathrm{Fe}_{4}^{\mathrm{III}}\left[\mathrm{Os}^{\mathrm{II}}(\mathrm{CN})_{6}\right]_{3}$-modified $\mathrm{TiO}_{2}$ materials (16-18, respectively) were fabricated and employed as bifunctional materials for the simultaneous detection and degradation of cyanide using the ICDA mechanism. ${ }^{32}$ The materials (16-18) were synthesized by stirring $\mathrm{K}_{4}\left[\mathrm{Fe}^{\mathrm{II}}(\mathrm{CN})_{6}\right]$, $\mathrm{K}_{4}\left[\mathrm{Ru}^{\mathrm{II}}(\mathrm{CN})_{6}\right]$, and $\mathrm{K}_{4}\left[\mathrm{OS}^{\mathrm{II}}(\mathrm{CN})_{6}\right]$, respectively, with 20 molar equivalents of $\mathrm{TiO}_{2}$, followed by the addition of 1.33 molar equivalents of $\mathrm{Fe}^{\mathrm{III}} \mathrm{Cl}_{3}$. The sizes of 16-18 were determined to be $28 \pm 2 \mathrm{~nm}, 27 \pm 2 \mathrm{~nm}$, and $27 \pm 2 \mathrm{~nm}$, respectively. These PBAs not only acted as 'colored coats' (16: blue, 17: purple, and 18: purple) but also quenched the photocatalytic properties of $\mathrm{TiO}_{2}$ (eqn (5)-(8)) by facilitating electron and hole recombination (eqn (9)-(11)) due to their metal-to-metal-ligand charge transfer (MMCT) properties.

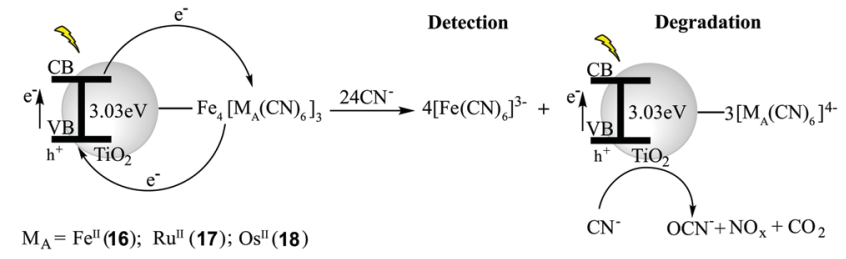

Fig. 10 The detection and degradation of $\mathrm{CN}^{-}$by 16-18 via the ICDA.

Upon exposure to cyanide, the disassembly of $\mathrm{Fe}^{\mathrm{III}}$ from the $\mathrm{TiO}_{2}$ on the PBAs resulted in release of a new $\mathrm{Fe}^{\mathrm{III}}$-cyanide adduct, which consequently interrupted the original MMCT of the PBA and restored the photocatalytic properties of $\mathrm{TiO}_{2}$ (Fig. 10). Among the tested organic and inorganic pollutants (e.g. cyanide, aniline, 1,5-naphthalenedisulfonic acid, benzoic acid, and 4-nitrophenol), only cyanide induced a selective colorimetric response (from a colored suspension to a white suspension), and triggered the photocatalytic activity of $\mathrm{TiO}_{2}$. Cyanide ions were subsequently catalytically photo-oxidized into the less toxic compounds cyanate, nitrite, nitrate, and $\mathrm{CO}_{2}$ by the released $\mathrm{TiO}_{2}-\left[\mathrm{M}_{\mathrm{A}}^{\mathrm{II}}(\mathrm{CN})_{6}\right]^{4-}$ material. The method detection limit (MDL) values of 16-18 for $\mathrm{CN}^{-}$were $1.10 \mathrm{mg} \mathrm{L}^{-1}, 0.60 \mathrm{mg} \mathrm{L}^{-1}$, and $0.83 \mathrm{mg} \mathrm{L}^{-1}$, respectively. The degradation efficiencies for 16-18 were found in the range 96.6-98.8\% for $\mathrm{CN}^{-}$, while for the other analytes the corresponding values ranged from $<0.2$ to $6.5 \%$. The detection and degradation of cyanide by 16-18 were also found to be applicable in tap and river water.

$$
\begin{gathered}
\mathrm{TiO}_{2}+h \nu \rightarrow \mathrm{e}^{-}+\text {hole }^{+} \\
\mathrm{O}_{2}+\mathrm{e}^{-} \rightarrow \mathrm{O}_{2}^{\bullet-} \\
0.5 \mathrm{O}_{2}^{\bullet-}+0.5 \mathrm{O}_{2}^{\bullet-}+\mathrm{H}^{+} \rightarrow 0.5 \mathrm{H}_{2} \mathrm{O}_{2}+0.5 \mathrm{O}_{2} \\
\mathrm{OH}^{-}+\text {hole }^{+} \rightarrow \mathrm{HO}^{\bullet} \\
\mathrm{e}^{-}+\text {hole }^{+} \rightarrow \text { recombination } \\
\mathrm{Fe}_{4}^{\mathrm{III}}\left[\mathrm{M}_{\mathrm{A}}^{\mathrm{II}}(\mathrm{CN})_{6}\right]_{3}+\mathrm{e}^{-} \rightarrow \mathrm{Fe}_{4}^{\mathrm{II}}\left[\mathrm{M}_{\mathrm{A}}^{\mathrm{II}}(\mathrm{CN})_{6}\right]_{3} \\
\mathrm{Fe}_{4}^{\mathrm{II}}\left[\mathrm{M}_{\mathrm{A}}^{\mathrm{II}}(\mathrm{CN})_{6}\right]_{3}+\text { hole }^{+} \rightarrow \mathrm{Fe}_{4}^{\mathrm{III}}\left[\mathrm{M}_{\mathrm{A}}^{\mathrm{II}}(\mathrm{CN})_{6}\right]_{3}
\end{gathered}
$$

\section{Catalyst/indicator-displacement assay (CIDA) for molecular detection and degradation}

As mentioned in Section 2, enhanced selectivity is an important property in molecular detection. Efforts toward the increase of the chemodosimetric selectivity by modification of receptors, signal transducers, bridges, and auxiliary ligands of signal transducers of BmDAEs have been discussed in Sections 2.2-2.3. In addition, the use of the catalytic function of BmDAEs is another approach. Typically, a catalyst is tailored to promote a specific transformation. Therefore, by integrating an active catalyst into a BmDAE (in contrast to the ICDA, in the present case no inhibitor is incorporated into it), a target analyte can be initially transformed into a compound with specific functionality that can be more easily recognized via the IDA mechanism. 
Accordingly, the selectivity of the chemosensing system is expected to increase through, this so-called, catalyst/indicatordisplacement assay (Scheme 3).

A novel $\mathrm{Ru}^{\mathrm{II}}-\mathrm{Cu}^{\mathrm{I}}$-based BmDAE, $\left[\mathrm{Ru}^{\mathrm{II}}(\mathrm{bpy})_{2}(\mathrm{CN})_{2}\right]_{2}-\left(\mathrm{Cu}^{\mathrm{I}} \mathrm{I}\right)_{2}$ (19) comprised of two active catalytic units $\left(\mathrm{Cu}^{\mathrm{I}}\right.$-catalyst $)$ and two signal transducer units $\left(\mathrm{Ru}^{\mathrm{II}}(\mathrm{bpy})_{2}(\mathrm{CN})_{2}\right)$, was synthesized for the detection of methyl parathion, a highly toxic organophosphate pesticide via the CIDA. ${ }^{33}$ Complex 19 was synthesized by stirring equimolar amounts of $\mathrm{Cu}^{\mathrm{I} I}$ and $\mathrm{Ru}(\mathrm{bpy}) 2(\mathrm{CN}) 2$ in a methanol/acetonitrile mixture $(1: 10 \mathrm{v} / \mathrm{v})$. The $\mathrm{Cu}^{\mathrm{I}}$ metallic receptor was employed because of its strong coordination to the phosphate ester group, ${ }^{34}$ and its function as a luminescent quencher for the ${ }^{3} \mathrm{MLCT}$ of $\mathrm{Ru}^{\mathrm{II}}(\mathrm{bpy})(\mathrm{CN})_{2}$. The crystal structure of 19 revealed its tetranuclear rhomboid configuration in which the two $\mathrm{Ru}^{\mathrm{II}}$ centers are cyano-bridged to the two $\mathrm{Cu}^{\mathrm{I}} \mathrm{I}$ centers.

Unlike IDA and ICDA, the phosphate ester group in methyl parathion cannot dissociate the BmDAE 19 due to its weak nucleophilicity. Interestingly, the active $\mathrm{Cu}^{\mathrm{I}}$ catalytic unit in 19 catalytically hydrolyzed the phosphate ester of methyl parathion into the UV/vis-active 4-nitrophenolate and the o,o-dimethyl thiophosphate (DTP) anions, the latter of which is a strong nucleophile. Because the $\Delta G^{\circ}$ of the $\mathrm{Cu}^{\mathrm{I}}(\mathrm{DTP})$ adduct formation $\left(-20.3 \mathrm{~kJ} \mathrm{~mol}^{-1}\right)$ is smaller than that of $19\left(-20.2 \mathrm{~kJ} \mathrm{~mol}^{-1}\right)$, the DTP interacted with the $\mathrm{Cu}^{\mathrm{I}}$ center in the bimetallic complex, displacing $\mathrm{Ru}^{\mathrm{II}}(\mathrm{bpy})_{2}(\mathrm{CN})_{2}$ and inducing a luminescence enhancement (Fig. 11). In contrast, as the active $\mathrm{Cu}^{\mathrm{I}}$ catalytic units of 19 cannot hydrolyze other aromatic and aliphatic organophosphate pesticides, including fenthion, mevinphos, terbufos, and phosalone, a luminescent response is not observed. Owing to the hydrolysis of methyl parathion via the CIDA, the pesticide toxicity was also reduced. The detection limit of complex 19 toward methyl parathion was determined to be $8 \mathrm{mg} \mathrm{\textrm {L } ^ { - 1 }}$.

\section{Catalyst-displacement assay (CDA) for molecular degradation}

The development of "smart" catalysts is crucial in both synthetic and applied chemistry. Traditionally, chemists develop catalysts to improve the yields, rates, and/or enantioselectivity of the desired transformation. However, unlike traditional catalysts that initiate a reaction only in the presence of reactants, "smart" catalysts can be developed by incorporating extra control parameters, including condition-selective receptors, thus enabling activity only under specific conditions. Recently, this type of

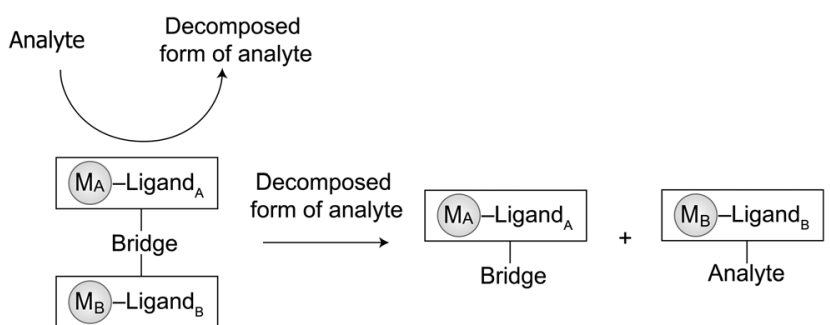

Scheme 3 BmDAEs for the degradation and detection of analytes through the CIDA.

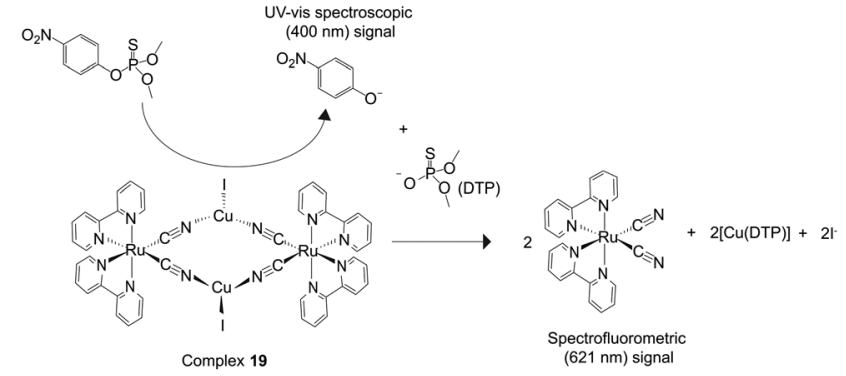

Fig. 11 The CIDA mechanism for the detection of methyl parathion by complex 19.

smart catalyst, so-called latent catalysts, have demonstrated "off-on" functionality under variable temperature conditions, ${ }^{35}$ the addition of a chemical agent, ${ }^{36}$ light irradiation, ${ }^{37}$ or mechanical forces. ${ }^{7 b}$ Although these result in interesting reaction outcomes, such latent catalysts have exhibited considerable constraints in terms of their molecular synthesis and monotonic on-off switching function. In this section, a new latent catalytic design composed of a metallic inhibitor and a metallic pre-catalyst, referred to the so-called catalyst-displacement assay (CDA), will be discussed. The use of BmDAE aims to relieve synthetic organic constraints during the synthesis of catalysts, while the CDA design not only renders them off-on latent catalysts, but also acts as a threshold switch for catalysis initiation once a reagent reaches a specific concentration (Scheme 4).

As mentioned in Sections 3.1-3.3, complex 14 was synthesized for the detection and degradation of cyanide via the ICDA (Fig. 8). The addition of cyanide to the ensemble initially led to dissociation of $\left[\mathrm{Cu}^{\mathrm{II}}(\text { dien })\right]^{2+}$ from the colored $\left[\mathrm{Fe}^{\mathrm{II}}\left({ }^{t} \mathrm{Bubpy}\right)(\mathrm{CN})_{4}\right]^{2-}$ unit, producing the $\left[\mathrm{Cu}^{\mathrm{II}}(\mathrm{dien})(\mathrm{CN})_{2}\right]$ adduct which was then used for degradation. In order to understand the CDA, a new $\mathrm{Fe}^{\mathrm{II}}-$ $\mathrm{Cu}^{\mathrm{II}}$-based BmDAE, $\mathrm{Fe}^{\mathrm{II}}(\mathrm{CN})_{6}-\left[\mathrm{Cu}^{\mathrm{II}}(\text { dien })\left(\mathrm{H}_{2} \mathrm{O}\right)\right]_{2}$ (20), in which the ferrocyanide unit can only provide its inhibiting functionality but not a signal-transducing function, was synthesized. ${ }^{38}$ Complex 20 is a stable BmDAE owing to the four negative charges in its ferrocyanide donating unit $\left(\Delta G^{\circ}=-30.4 \mathrm{~kJ} \mathrm{~mol}^{-1}\right)$. The $\left[\mathrm{Fe}^{\mathrm{II}}(\mathrm{CN})_{6}\right]^{4-}$ unit in 20 uses two of its cyano-units to bridge with two $\mathrm{Cu}^{\mathrm{II}}$ receptors, as verified by ESI-MS and FTIR.

Upon addition of cyanide to 20, the displacement of [ $\mathrm{Cu}^{\mathrm{II}}$ $($ dien $)]^{2+}$ from $\left[\mathrm{Fe}^{\mathrm{II}}(\mathrm{CN})_{6}\right]^{4-}$ took place, and formation of the $\left[\mathrm{Cu}^{\mathrm{II}}(\right.$ dien $\left.)(\mathrm{CN})_{2}\right]$ adduct with a $\Delta G^{\circ}$ of $-37.9 \mathrm{~kJ} \mathrm{~mol}^{-1}$ occurred. Interestingly, complex 20 did not exhibit catalytic properties for cyanide concentrations below $200 \mu \mathrm{M}$ (Fig. 12). To understand this observation, the cleavage rate constant for the cyanobridges by free cyanide was studied and found to be $18.8 \mathrm{M}^{-1} \mathrm{~s}^{-1}$.

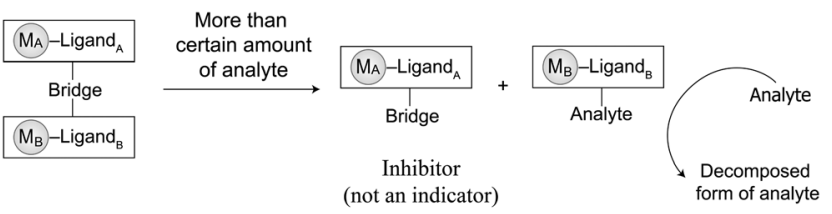

Scheme 4 BmDAEs for the "threshold-controlled off-on" degradation of analytes through the CDA. 

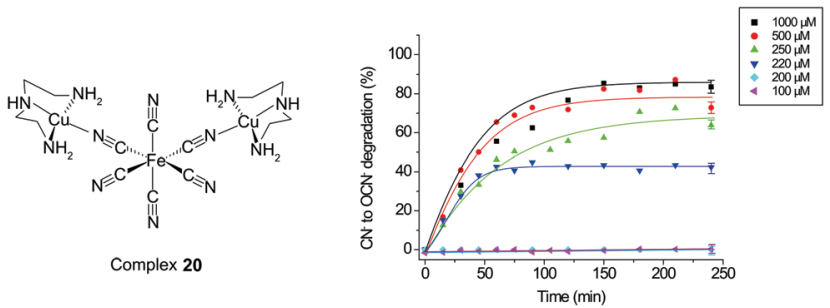

Fig. 12 The "threshold-controlled" latent catalyst 20 operates via the CDA mechanism to degrade cyanide.

This result shows that, despite the favorable thermodynamics of dissociation of 20 by cyanide with concomitant formation of the more stable $\left[\mathrm{Cu}^{\mathrm{II}}(\mathrm{dien})(\mathrm{CN})_{2}\right]$ adduct, the bridge cleavage by cyanide is limited by a kinetic factor. Therefore, the cleavage of $\mathbf{2 0}$ is triggered once the initial cyanide concentration exceeds $200 \mu \mathrm{M}$, subsequently releasing $\left[\mathrm{Cu}^{\mathrm{II}}(\mathrm{dien})(\mathrm{CN})_{2}\right]$ for further catalytic cyanide oxidation. Through the CDA, the BmDAEs functioned as "thresholdcontrolled" latent catalysts.

Finally, through the BmDAE based CDA, the new, less strongly bound BmDAE $\left\{\left[\mathrm{Fe}^{\mathrm{II}(}\left({ }^{\mathrm{Bubpy}}\right)_{2}(\mathrm{CN})_{2}\right]_{2}-\left[\mathrm{Cu}^{\mathrm{II}}(\right.\right.$ dien $\left.\left.)\right]\right\} \mathrm{Cl}_{2}$ (21, $\Delta G^{\circ}=-15.1 \mathrm{~kJ} \mathrm{~mol}^{-1}$ with cleavage rate constant of $58.3 \mathrm{M}^{-1} \mathrm{~s}^{-1}$ ) which is the analogue of 12 , was synthesized. With regard to its structure, the $\mathrm{Cu}^{\mathrm{II}}$ receptor is cyano-bridged

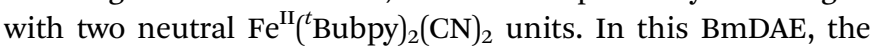
catalytic oxidation of cyanide requires a threshold concentration of $0.50 \mathrm{mg} \mathrm{L}^{-1}$, which is the suggested maximum allowed level of cyanide in wastewater by the European International organization (Fig. 13). ${ }^{39}$

In further studies, both domestic and industrial real wastewater samples were collected and spiked with cyanide to achieve concentrations of $0.25 \mathrm{mg} \mathrm{L}^{-1}, 0.50 \mathrm{mg} \mathrm{L}^{-1}$, or $0.75 \mathrm{mg} \mathrm{L}^{-1}$. The degradation/oxidation of cyanide in these samples was analyzed at $298 \mathrm{~K}$ with complex 21 in the presence of $\mathrm{H}_{2} \mathrm{O}_{2}$. The results revealed that the oxidation of $\mathrm{CN}^{-}$was initiated from $0.50 \mathrm{mg} \mathrm{L}^{-1}$,

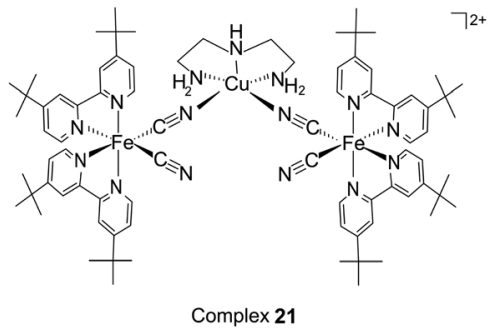

\begin{tabular}{cccc}
\hline $\begin{array}{c}\text { Wastewater } \\
\text { samples }\end{array}$ & $\begin{array}{c}\text { Cyanide } \\
\text { added } \\
(\mathrm{mg} / \mathrm{L})\end{array}$ & $\begin{array}{c}\text { Cyanate } \\
\text { generated } \\
(\mathrm{mg} / \mathrm{L})\end{array}$ & $\begin{array}{c}\text { Conversion } \\
\text { after } 4 \mathrm{~h} \\
(\%)\end{array}$ \\
\hline $\begin{array}{c}\text { Domestic } \\
\text { (level l, } \\
\text { untreated) }\end{array}$ & 0.25 & 0 & 0 \\
\hline & 0.50 & 0.153 & 30.4 \\
Industrial & 0.75 & 0.323 & 42.9 \\
\hline & 0.50 & 0 & 0 \\
& 0.75 & 0.165 & 33.1 \\
\hline
\end{tabular}

Fig. 13 Results of cyanide degradation by $\mathbf{2 1}$ in domestic (level I, untreated) and industrial wastewater samples. resulting in $30.4-33.1 \% \mathrm{OCN}^{-}$content (Fig. 13). However, in samples with a below-threshold cyanide concentration of $0.25 \mathrm{mg} \mathrm{L}^{-1}$, neither the oxidation of $\mathrm{CN}^{-}$nor the formation of $\mathrm{OCN}^{-}$were detected throughout the duration of the test. The overall results indicate that the CDA concept is applicable to real wastewater samples, even in the presence of organic and inorganic residues.

\section{Conclusion}

The disassembly is an important process in supramolecular chemistry, through which numerous catalysts and molecular detectors have been developed. This review discussed the use of BmDAEs as the supramolecular systems to study the disassembly between metallic donors and acceptors. Four different displacement assays, IDA, ICDA, CIDA, and CDA, have been developed with the incorporation of signal transducers, receptors, inhibitors, catalysts, and pre-catalysts in the donor/acceptor pair of BmDAEs for pollutant degradation and detection. Importantly, the control of supramolecular dissociation sequence is the key to these systems. Moving forward, the exchange of molecular units must be further studied to demonstrate the adaptability and evolution of supramolecular systems in response to environmental changes. Reversibility and dynamics are important characteristics that should be taken into account for the future development of related functional materials.

\section{Conflicts of interest}

There are no conflicts to declare.

\section{Acknowledgements}

CF is grateful for the Croucher Fellowship (2005-2007) from The Croucher Foundation and guidance from Prof Jean Marie Lehn during his post-doc training. The authors would also like to thank The Education University of Hong Kong and the Research Grants Council of Hong Kong SAR, China for financial support.

\section{References}

1 (a) J. M. Lehn, Toward self-organization and complex matter, Science, 2002, 295, 2400-2403; (b) J. M. Lehn, in Supramolecular science: where it is and where it is going, ed. R. Ungaro and E. Dalcanale, Kluwer, Dordrecht, 1999, pp. 287-304.

2 C. Bohne, Supramolecular dynamics, Chem. Soc. Rev., 2014, 43, 4037-4050.

3 (a) S. Wang, W. Gao, X.-Y. Hu, Y.-Z. Shen and L. Wang, Supramolecular strategy for smart windows, Chem. Commun., 2019, 55, 4137-4149; (b) M. Raynal, P. Ballester, A. Vidal-Ferran and P. W. N. M. van Leeuwen, Supramolecular catalysis. Part 1: non-covalent interactions as a tool for building and modifying homogeneous catalysts, Chem. Soc. Rev., 2014, 43, 1660-1733; (c) I. V. Kolesnichenko and E. V. Anslyn, Practical applications 
of supramolecular chemistry, Chem. Soc. Rev., 2017, 46, 2385-2390; (d) Z. Feng, T. Zhang, H. Wang and B. Xu, Supramolecular catalysis and dynamic assemblies for medicine, Chem. Soc. Rev., 2017, 46, 6470-6479; (e) J. W. Fredy, A. Méndez-Ardoy, S. Kwangmettatam, D. Bochicchio, B. Matt, M. C. A. Stuart, J. Huskens, N. Katsonis, G. M. Pavan and T. Kudernac, Molecular photoswitches mediating the straindriven disassembly of supramolecular tubules, Proc. Natl. Acad. Sci. U. S. A., 2017, 114, 11850-11855.

4 (a) N. Hafezi and J. M. Lehn, Adaptation of dynamic covalent systems of imine constituents to medium change by component redistribution under reversible phase separation, J. Am. Chem. Soc., 2012, 134, 12861-12868; (b) V. Berl, I. Huc, R. G. Khoury, M. J. Krische and J. M. Lehn, Interconversion of single and double helices formed from synthetic molecular strands, Nature, 2000, 407, 720-723.

5 T. D. Pollard and J. A. Cooper, Actin, a central player in cell shape and movement, Science, 2009, 326, 1208-1212.

6 (a) Y.-F. Li, Y.-M. Sun, R. C. Beier, H.-T. Lei, S. Gee, B. D. Hammock, H. Wang, Z. Wang, X. Sun, Y.-D. Shen and Z.-L. Xu, Immunochemical techniques for multianalyte analysis of chemical residues in food and the environment: A review, TrAC, Trends Anal. Chem., 2017, 88, 25-40; (b) S. Y. Toh, M. Citartan, S. C. B. Gopinath and T.-H. Tang, Aptamers as a replacement for antibodies in enzymelinked immunosorbent assay, Biosens. Bioelectron., 2015, 64, 392-403; (c) S. L. Wiskur, H. Ait-Haddou, J. J. Lavigne and E. V. Anslyn, Teaching old indicators new tricks, Acc. Chem. Res., 2001, 34, 963-972.

7 (a) S. Monsaert, A. L. Vila, R. Drozdzak, P. Van der Voort and F. Verpoort, Latent olefin metathesis catalysts, Chem. Soc. Rev., 2009, 38, 3360-3372; (b) A. Piermattei, S. Karthikeyan and R. P. Sijbesma, Activating catalysts with mechanical force, Nat. Chem., 2009, 1, 133.

8 (a) E. J. O'Neil and B. D. Smith, Anion recognition using dimetallic coordination complexes, Coord. Chem. Rev., 2006, 250, 3068-3080; (b) N. Wheatley and P. Kalck, Structure and reactivity of early-late heterobimetallic complexes, Chem. Rev., 1999, 99, 3379; (c) E. L. Dias and R. H. Grubbs, Synthesis and investigation of homo-and heterobimetallic ruthenium olefin metathesis catalysts exhibiting increased activities, Organometallics, 1998, 17, 2758; (d) C. F. Chow, S. Fujii and J. M. Lehn, Metallodynamers: neutral dynamic metallosupramolecular polymers displaying transformation of mechanical and optical properties on constitutional exchange, Angew. Chem., Int. Ed., 2007, 46, 5007; (e) C. F. Chow, S. Fujii and J. M. Lehn, Metallodynamers: Neutral Double-Dynamic Metallosupramolecular Polymers, Chem. - Asian J., 2008, 3, 1324; $(f)$ M. Shibasaki, H. Sasai and T. Arai, Asymmetric catalysis with heterobimetallic compounds, Angew. Chem., Int. Ed. Engl., 1997, 36, 1237; (g) C. J. Shorrock, B. Y. Xue, P. B. Kim, R. J. Batchelor, B. O. Patrick and D. B. Leznoff, Heterobimetallic Coordination Polymers Incorporating $\left[\mathrm{M}(\mathrm{CN})_{2}\right]^{-}(\mathrm{M}=\mathrm{Cu}, \mathrm{Ag})$ and $\left[\mathrm{Ag}_{2}(\mathrm{CN})_{3}\right]^{-}$Units: Increasing Structural Dimensionality via $\mathbf{M}-\mathbf{M}^{\prime}$ and $\mathbf{M} \cdots \mathrm{NC}$ Interactions, Inorg. Chem., 2002, 41, 6743.
9 (a) L. Zhu and E. V. Anslyn, Signal amplification by allosteric catalysis, Angew. Chem., Int. Ed., 2006, 45, 1190-1196; (b) J. M. Lehn, Perspectives in chemistry-aspects of adaptive chemistry and materials, Angew. Chem., Int. Ed., 2015, 54, 3276-3289.

10 I. V. Kolesnichenko and E. V. Anslyn, Practical applications of supramolecular chemistry, Chem. Soc. Rev., 2017, 46, 2385-2390.

11 (a) F. Y. Thanzeel, A. Sripada and C. Wolf, Quantitative Chiroptical Sensing of Free Amino Acids, Biothiols, Amines, and Amino Alcohols with an Aryl Fluoride Probe, J. Am. Chem. Soc., 2019, 141, 16382-16387; (b) X. Liu, D. G. Smith and K. A. Jolliffe, Are two better than one? Comparing intermolecular and intramolecular indicator displacement assays in pyrophosphate sensors, Chem. Commun., 2016, 52, 8463-8466; (c) Y. Sasaki, É. Leclerc, V. Hamedpour, R. Kubota, S. Takizawa, Y. Sakai and T. Minami, Simplest Chemosensor Array for Phosphorylated Saccharides, Anal. Chem., 2019, 91, 15570-15576.

12 (a) S. H. Kim, H. S. Choi, J. Kim, S. J. Lee, D. T. Quang and J. S. Kim, Novel optical/electrochemical selective 1,2,3triazole ring-appended chemosensor for the $\mathrm{Al}^{3+}$ ion, $\mathrm{Org}$. Lett., 2010, 12, 560-563; (b) R. Kaushik, R. Sakla, A. Ghosh, S. Dama, A. Mittal and D. A. Jose, Copper ComplexEmbedded Vesicular Receptor for Selective Detection of Cyanide Ion and Colorimetric Monitoring of Enzymatic Reaction, ACS Appl. Mater. Interfaces, 2019, 11, 47587-47595; (c) M. A. Beatty, A. J. Selinger, Y. Q. Li and F. Hof, Parallel Synthesis and Screening of Supramolecular Chemosensors that Achieve Fluorescent Turn-On Detection of Drugs in Saliva, J. Am. Chem. Soc., 2019, 141, 16763-16771.

13 A. W. Czarnik, Fluorescent chemosensors of ion and molecule recognition, ACS Press, Washington, D. C., 1992.

14 (a) M. A. Hortala, L. Fabbrizzi, N. Marcotte, F. Stomeó and A. Taglietti, Designing the selectivity of the fluorescent detection of amino acids: a chemosensing ensemble for histidine, J. Am. Chem. Soc., 2003, 125, 20; (b) L.-X. Huang, Q. Guo, Y. Chen, P. Verwilst, S. Son, J.-B. Wu, Q.-Y. Cao and J. S. Kim, Nanomolar detection of adenosine triphosphate (ATP) using a nanostructured fluorescent chemosensing ensemble, Chem. Commun., 2019, 55, 14135-14138; (c) D. Jimenez, R. Martinez-Manez, F. Sancenon, J. V. RosLis, A. Benito and J. Soto, A new chromo-chemodosimeter selective for sulfide anion, J. Am. Chem. Soc., 2003, 125, 9000; (d) M. Comes, G. Rodriguez-Lopez, M. D. Marcos, R. Martinez-Manez, F. Sancenon, J. Soto, L. A. Villaescusa, P. Amoros and D. Beltran, Host Solids Containing Nanoscale Anion-Binding Pockets and Their Use in Selective Sensing Displacement Assays, Angew. Chem., Int. Ed., 2005, 44, 2918; (e) Y. Sasaki, Z. Zhang and T. Minami, A Saccharide Chemosensor Array Developed Based on an Indicator Displacement Assay Using a Combination of Commercially Available Reagents, Front. Chem., 2019, 7, 49.

15 (a) C. F. Chow, B. K. W. Chiu, M. H. W. Lam and W. Y. Wong, A trinuclear heterobimetallic $\mathrm{Ru}(\mathrm{II}) / \mathrm{Pt}(\mathrm{II})$ complex as a chemodosimeter selective for sulfhydryl-containing amino 
acids and peptides, J. Am. Chem. Soc., 2003, 125, 7802-7803; (b) C. F. Chow, M. H. W. Lam and W. Y. Wong, Design and synthesis of heterobimetallic donor-acceptor chemodosimetric ensembles for the detection of sulfhydryl-containing amino acids and peptides, Dalton Trans., 2005, 475-484; (c) C. F. Chow, M. H. W. Lam and W. Y. Wong, A heterobimetallic ruthenium(II)-copper(II) donor-acceptor complex as a chemodosimetric ensemble for selective cyanide detection, Inorg. Chem., 2004, 43, 8387; (d) C. K. Koo, C. F. Chow, B. K. W. Chiu, M. H. W. Lam and W. Y. Wong, A Pair of Coordination Donor-Acceptor Ensembles for the Detection of Tartrate in Aqueous Media, Eur. J. Inorg. Chem., 2008, 1318; (e) C. F. Chow, H. K. Kong, S. W. Leung, B. K. W. Chiu, C. K. Koo, E. N. Y. Lei, M. H. W. Lam, W. T. Wong and W. Y. Wong, Heterobimetallic Ru(II)-Eu(III) complex as chemodosimeter for selective biogenic amine odorants detection in fish sample, Anal. Chem., 2011, 83, 289; ( $f$ ) C. F. Chow, M. H. W. Lam and W. Y. Wong, Design and synthesis of heterobimetallic $\mathrm{Ru}(\mathrm{II})-\mathrm{Ln}$ (III) complexes as chemodosimetric ensembles for the detection of biogenic amine odorants, Anal. Chem., 2013, 85, 8246-8253; $(g)$ C. F. Chow, K. Y. F. Ho and C. B. Gong, Synthesis of a new bimetallic Re(I)-NCS-Pt(II) complex as chemodosimetric ensemble for the selective detection of mercapto-containing pesticides, Anal. Chem., 2015, 87, 6112-6118; (h) C. F. Chow, F. W. Gong and C. B. Gong, Chemodosimetric analysis in food-safety monitoring: design, synthesis, and application of a bimetallic $\mathrm{Re}(\mathrm{I})-\mathrm{Pt}(\mathrm{II})$ complex for detection of dimethyl sulfide in foods, Analyst, 2014, 139, 4532-4537; (i) C. F. Chow, P. Y. Ho, Y. J. Lu, W. L. Wong, Q. Tang and C. B. Gong, Development of sensitive and selective food sensors using new Re(I)-Pt(II) bimetallic complexes to detect volatile biogenic sulfides formed by meat spoilage, Food Chem., 2017, 216, 382-389; (j) C. F. Chow, S. Liu, C. W. Chan, Y. J. Lu, W. L. Wong, Q. Tang and C. B. Gong, A bimetallic Re(I)-NCS-Pt(II) solidsupport chemosensor for the selective detection of dimethyl sulfide in spoiled meat, Sens. Actuators, B, 2018, 255, 2298-2305.

16 (a) M. E. Howe-Grant and S. J. Lippard, in Metal Ions in Biological Systems, ed. H. Siegel, Dekker, New York, 1980, vol. 11, pp. 63-125; (b) S. Swavey, Z. Fang and K. J. Brewer, Mixed-metal supramolecular complexes coupling phosphinecontaining $\mathrm{Ru}(\mathrm{II})$ light absorbers to a reactive $\mathrm{Pt}(\mathrm{II})$ through polyazine, bridging ligands, Inorg. Chem. 2002, 41, 2598; (c) C. A. Bignozzi and F. Scandola, Cyano-bridged ruthenium(II)/ platinum(II) complexes: synthesis, photophysical properties, and excited-state redox behaviour, Inorg. Chem., 1984, 23, 1540; (d) N. Kitamura, M. Sato, H. B. Kim, R. Obata and S. Tazuke, Solvatochromism in the excited state of the cis-dicyanobis (1,10-phenanthroline)ruthenium(II) complex, Inorg. Chem., 1988, 27, 651.

17 A. Hubaux and G. Vos, Decision and detection limits for calibration curves, Anal. Chem., 1970, 42, 849-855.

18 J. L. Sessler, P. A. Gale and W. S. Cho, Anion Receptor Chemistry, RSC Press, London, 2006, ch. 7, pp. 63-125.

19 (a) G. C. Miller and C. A. Pritsos, Cyanide: Soc., Ind. Econ. Aspects, Proc. Symp. Annu. Meet. TMS, 2001, 73; (b) D. Shan,
C. Mousty and S. Cosnier, Subnanomolar cyanide detection at polyphenol oxidase/clay biosensors, Anal. Chem., 2004, 76, 178; (c) C. O. Ikediobi, L. Wen and L. M. Latinwo, Pesticide analysis by solid-phase microextraction, Am. Environ. Lab., 1997, 9, 20; (d) E. Gail, S. Gos, R. Kulzer, J. Lorösch, A. Rubo, M. Sauer, R. Kellens, J. Reddy, N. Steier and W. Hasenpusch, Cyano Compounds, Inorganic, in Ullmann's Encyclopedia of Industrial Chemistry, Wiley-VCH Verlag GmbH \& Co. KGaA, Weinheim, Germany, 2011; (e) X.-X. Ou, Y.-L. Jin, X.-Q. Chen, C. B. Gong, X.-B. Ma, Y.-S. Wang, C. F. Chow and Q. Tang, Colorimetric test paper for cyanide ion determination in realtime, Anal. Methods, 2015, 7, 5239-5244.

20 (a) Z. Xu, X. Chen, H. N. Kim and J. Yoon, Sensors for the optical detection of cyanide ion, Chem. Soc. Rev., 2010, 39, 127-137; (b) F. Wang, L. Wang, X. Chen and J. Yoon, Recent progress in the development of fluorometric and colorimetric chemosensors for detection of cyanide ions, Chem. Soc. Rev., 2014, 43, 4312-4324.

21 (a) S. L. Taylor, Histamine food poisoning: toxicology and clinical aspects, CRC Crit. Rev. Toxicol., 1986, 17, 91; (b) J. D. Morrow, G. R. Margolies, J. Rowland and L. J. N. Roberts, Evidence that histamine is the causative toxin of scombroid-fish poisoning, Engl. J. Med., 1991, 324, 716; (c) R. M. Wachter and G. S. Kaveh, The unintended consequences of measuring quality on the quality of medical care, Engl. J. Med., 2000, 342, 520; (d) M. A. Banchaabouchi, B. Marescau, R. D’Hooge, S. Engelborgh and P. P. De Deyn, Consequences of renal mass reduction on amino acid and biogenic amine levels in nephrectomized mice, Amino Acids, 2000, 18, 265; (e) Decomposition \& Histamine in Albacore, Skipjack, and Yellowfin Tuna, FDA/ORA Compliance Policy Guide, 2004 revision, Subchapter 540.525; FDA: Washington, DC, 2004.

22 (a) H. Zhou, L. Baldini, J. Hong, A. J. Wilson and A. D. Hamilton, Pattern recognition of proteins based on an array of functionalized porphyrins, J. Am. Chem. Soc., 2006, 128, 2421-2425; (b) N. A. Rakow, A. Sen, M. C. Janzen, J. B. Ponder and K. S. Suslick, Molecular recognition and discrimination of amines with a colorimetric array, Angew. Chem., Int. Ed., 2005, 44, 4528-4532; (c) G. A. Sotzing, J. N. Phend, R. H. Grubbs and N. S. Lewis, Highly sensitive detection and discrimination of biogenic amines utilizing arrays of polyaniline/carbon black composite vapor detectors, Chem. Mater., 2000, 12, 593-595.

23 (a) R. T. Marsili, SPME-MS-MVA as an Electronic Nose for the Study of Off-Flavors in Milk, J. Agric. Food Chem., 1999, 47, 648; (b) V. Varlet and X. Fernandez, Sulfur-containing volatile compounds in seafood: occurrence, odorant properties and mechanisms of formation, Food Sci. Technol. Int., 2010, 16, 463; (c) A. Isogal, R. Kanda, Y. Hiraga, T. Nishimura, $\mathrm{H}$. Iwata and N. Goto-Yamamoto, Screening and identification of precursor compounds of dimethyl trisulfide (DMTS) in Japanese sake, J. Agric. Food Chem., 2009, 57, 189; (d) T. M. Lovestead and T. J. Bruno, Detection of poultry spoilage markers from headspace analysis with cryoadsorption on a short alumina PLOT column, Food Chem., 2010, 121, 1274; 
(e) Scientifc Opinion on Flavouring Group Evaluation 74, Revision 1 (FGE.74Rev1), 2009.

24 C. F. Chow, P. Y. Ho and C. B. Gong, An Ru(II)-Fe(III) bimetallic complex as a multifunctional device for detecting, signal amplifying, and degrading oxalate, Analyst, 2014, 139, 4256-4263.

25 C. F. Chow, P. Y. Ho, W. L. Wong and C. B. Gong, A Multifunctional Bimetallic Molecular Device for Ultrasensitive Detection, Naked-Eye Recognition, and Elimination of Cyanide Ions, Eur. J. Chem., 2015, 21, 12984-12990.

26 (a) H. Cheung, R. S. Tanke and G. P. Torrence, Ullmann's Encyclopedia of Industrial Chemistry, 2000; (b) A. Sjode, S. Winestrand, N. O. Nilvebrant and L. J. Jonsson, Enzymebased control of oxalic acid in the pulp and paper industry, Enzyme Microbiol. Technol., 2008, 43, 78; (c) G. P. Kasidas and G. A. Rose, Measurement of plasma oxalate in healthy subjects and in patients with chronic renal failure using immobilised oxalate oxidase, Clin. Chim. Acta, 1986, 154, 49.

27 (a) C. Walling and K. Amarnath, Oxidation of mandelic acid by Fenton's reagent, J. Am. Chem. Soc., 1982, 104, 1185; (b) H. Lim, J. Lee, S. Jin, J. Kim, J. Yoon and T. Hyeon, Highly active heterogeneous Fenton catalyst using iron oxide nanoparticles immobilized in alumina coated mesoporous silica, Chem. Commun., 2006, 463.

28 Q. Wu and E. V. Anslyn, Catalytic signal amplification using a Heck reaction. An example in the fluorescence sensing of $\mathrm{Cu}^{(\mathrm{II})}$, J. Am. Chem. Soc., 2004, 126, 14682-14683.

29 (a) P. Scrimin and L. J. Prins, Sensing through signal amplification, Chem. Soc. Rev., 2011, 40, 4488-4505; (b) R. Bonomi, A. Cazzolaro, A. Sansone, P. Scrimin and L. J. Prins, Detection of enzyme activity through catalytic signal amplification with functionalized gold nanoparticles, Angew. Chem., Int. Ed., 2011, 50, 2307.

30 (a) N. Graf and R. Kramer, Enzymatic amplification in a bioinspired, autonomous signal cascade, Chem. Commun., 2006, 4375; (b) M. S. Baker and S. T. Phillips, A two-component small molecule system for activity-based detection and signal amplification: application to the visual detection of threshold levels of $\mathrm{Pd}^{(\mathrm{II})}$, J. Am. Chem. Soc., 2011, 133, 5170; (c) M. A. Swiderska and J.-L. Reymond, Analytical chemistry: a dendritic signal amplifier, Nat. Chem., 2009, 1, 527; (d) N. Graf, M. Goritz and R. Kramer, A metal-ion-releasing probe for DNA detection by catalytic signal amplification, Angew. Chem., Int. Ed., 2006, 45, 4013; (e) M. S. Baker and S. T. Phillips, A small molecule sensor for fluoride based on an autoinductive, colorimetric signal amplification reaction,
Org. Biomol. Chem., 2012, 10, 3595; $(f)$ M. S. Masar III, N. C. Gianneschi, C. G. Oliveri, C. L. Stern, S. T. Nguyen and C. A. Mirkin, Allosterically regulated supramolecular catalysis of acyl transfer reactions for signal amplification and detection of small molecules, J. Am. Chem. Soc., 2007, 129, 10149.

31 (a) C. Shen, Q. Tang, C. B. Gong and C. F. Chow, Catalyst + Chemodosimeter $\rightarrow$ Chemosensor: incorporation of a catalytic functionality in an indicator displacement assay to realize reversible chemosensing detection, J. Mater. Chem. C, 2020, DOI: 10.1039/C9TC06308K; (b) M. T. Beck, Critical survey of stability constants of cyano complexes, Pure Appl. Chem., 1987, 59, 1703.

32 C. Shen, A. Zheng, M. Huang, Q. Tang, C. B. Gong and C. F. Chow, Indicator/catalyst displacement assay: design of a latent catalyst for the selective detection and degradation of cyanide by Prussian blue analog-modified $\mathrm{TiO}_{2}$ nanoparticles, J. Mater. Chem. C, 2019, 7, 8585.

33 A. Zheng, C. Shen, Q. Tang, C. B. Gong and C. F. Chow, Catalytic chemosensing assay for selective detection of methyl parathion organophosphate pesticide, Eur. J. Chem., 2019, 25, 9643-9649.

34 J. S. Yadav, R. K. Mehrotra and G. Srivastava, Metal and organometal complexes of oxy-and thiophosphorus acids. VIII. Reactions of $o, o$-diisopropyl and o,o-alkylene dithiophosphoric acidsh titanium and tin tetrachloride, Phosphorus, Sulfur Silicon Relat. Elem., 1991, 62, 169.

35 T. Ung, A. Hejl, R. H. Grubbs and Y. Schrodi, Latent ruthenium olefin metathesis catalysts that contain an N-heterocyclic carbene ligand, Organometallics, 2004, 23, 5399-5401.

36 B. K. Keitz and R. H. Grubbs, A tandem approach to photoactivated olefin metathesis: combining a photoacid generator with an acid activated catalyst, J. Am. Chem. Soc., 2009, 131, 2038-2039.

37 A. Ben-Asuly, A. Aharoni, C. E. Diesendruck, Y. Vidavsky, I. Goldberg, B. F. Straub and N. G. Lemcoff, Photoactivation of ruthenium olefin metathesis initiators, Organometallics, 2009, 28, 4652-4655.

38 C. F. Chow, P. Y. Ho, W. L. Wong, Y. J. Lu, Q. Tang and C. B. Gong, Catalyst displacement assay: a supramolecular approach for the design of smart latent catalysts for pollutant monitoring and removal, Chem. Sci., 2017, 8, 3812-3820.

39 R. R. Dash, A. Gaur and C. Balomajumder, Cyanide in industrial wastewaters and its removal: a review on biotreatment, J. Hazard. Mater., 2009, 163, 1-11. 